\title{
Research into Dissociation Zones of Gas Hydrate Deposits with a Heterogeneous Structure in the Black Sea
}

\author{
Oleg Bazaluk ${ }^{1, *(\mathbb{D}}$, Kateryna Sai $^{2}$, Vasyl Lozynskyi ${ }^{2, *\left(\mathbb{D}, \text { Mykhailo Petlovanyi }^{2} \mathbb{D} \text { and Pavlo Saik }\right.}{ }^{2}$ \\ 1 Belt and Road Initiative Centre for Chinese-European Studies, Guangdong University of Petrochemical \\ Technology, Maoming 525000, China \\ 2 Department of Mining Engineering and Education, Dnipro University of Technology, 49005 Dnipro, Ukraine; \\ kateryna.sai@gmail.com (K.S.); petlyovany@ukr.net (M.P.); saik.nmu@gmail.com (P.S.) \\ * Correspondence: bazaluk@ukr.net (O.B.); lvg.nmu@gmail.com (V.L.)
}

check for

updates

Citation: Bazaluk, O.; Sai, K.; Lozynskyi, V.; Petlovanyi, M.; Saik, P. Research into Dissociation Zones of Gas Hydrate Deposits with a

Heterogeneous Structure in the Black Sea. Energies 2021, 14, 1345. https:// doi.org/10.3390/en14051345

Academic Editors: Federico Rossi, Beatrice Castellani and Nicolas von Solms

Received: 29 December 2020

Accepted: 24 February 2021

Published: 2 March 2021

Publisher's Note: MDPI stays neutral with regard to jurisdictional claims in published maps and institutional affiliations.

Copyright: (C) 2021 by the authors Licensee MDPI, Basel, Switzerland. This article is an open access article distributed under the terms and conditions of the Creative Commons Attribution (CC BY) license (https:// creativecommons.org/licenses/by/ $4.0 /)$.

\begin{abstract}
Ukraine is an energy-dependent country, with less that $50 \%$ of its energy consumption fulfilled by its own resources. Natural gas is of paramount importance, especially for industry and society. Therefore, there is an urgent need to search for alternative and potential energy sources, such as gas hydrate deposits in the Black Sea, which can reduce the consumption of imported gas. It is necessary to refine the process parameters of the dissociation of gas hydrate deposits with a heterogeneous structure. The analyzed known geological-geophysical data devoted to the study of the offshore area and the seabed give grounds to assert the existence of a significant amount of hydrate deposits in the Black Sea. An integrated methodological approach is applied, which consists of the development of algorithms for analytical and laboratory studies of gas volumes obtained during the dissociation of deposits with a heterogeneous structure. These data are used for the computer modelling of the dissociation zone in the Surfer-8.0 software package based on the data interpolation method, which uses three methods for calculating the volumes of modelling bodies. A 3D grid-visualization of the studied part of the gas hydrate deposit has been developed. The dissociation zone parameters of gas hydrate deposits with different shares of rock intercalation, that is, the minimum and maximum diameters, have been determined, and the potentially recoverable gas volumes have been assessed. The effective time of the process of gas hydrate deposit dissociation has been substantiated. The obtained research results of the dissociation process of gas hydrate deposits can be used in the development of new technological schemes for gas recovery from the deep-water Black Sea area.
\end{abstract}

Keywords: gas hydrate; methane; rock; dissociation process; Black Sea; Ukraine

\section{Introduction \\ 1.1. Background of the Study}

Ukraine is a country experiencing energy shortages that has less than $50 \%$ of its energy resource needs met through its own production means [1]. In particular, in terms of imported natural gas consumption per capita, Ukraine from year to year occupies a leading position in the world. At present, coal and natural gas are the main types of state fuel and energy resources [2-4]. The coal industry is still a major component of the national economy after metallurgy [5-9]. This has been facilitated by the introduction of domestic coal mining enterprises and innovative technological solutions for mining bituminous coal and its associated useful components, such as coalbed methane [10-13].

Efficient technologies that may well compete with traditional mining methods include the underground coal gasification of balance reserves of abandoned mine fields, of which the implementation experience and related scientific research have been sufficiently studied [14-16].

In addition, cogeneration units can be applied, which allow the use of methane gas from degassing wells for heating the surface complex of coal mines $[17,18]$. 
However, the availability and timely delivery of liquid hydrocarbon energy resources, such as natural gas and oil, are essential conditions of the normal functioning of the economy not only in Ukraine, but also in most European countries $[19,20]$. The reverse side of this situation in Ukraine is the high dependence and vulnerability of the national economy on external environmental factors [21]. That is why the issue of state energy security, in particular the formation of an optimal strategy in the world energy markets, the effective use of competitive advantages, and the improvement of energy efficiency through the introduction and development of alternative fuels, is extremely important [22-27].

In 2019, Ukraine ranked 4th among European countries in terms of natural gas output, which in this year was 1.3\% lower compared to 2018. The largest share of gas is produced from fields discovered back in the Soviet times. All of them are depleted by $75-85 \%$, and this is one of the main reasons for the stagnation we see today in the industry. The decline in gas output in 2019 indicates that old fields continue to be used until they are completely depleted and new ones are not expected to be discovered [28-30]. The volumes of gas produced by national companies in Ukraine during 2016-2019 are shown in Figure 1 [31].

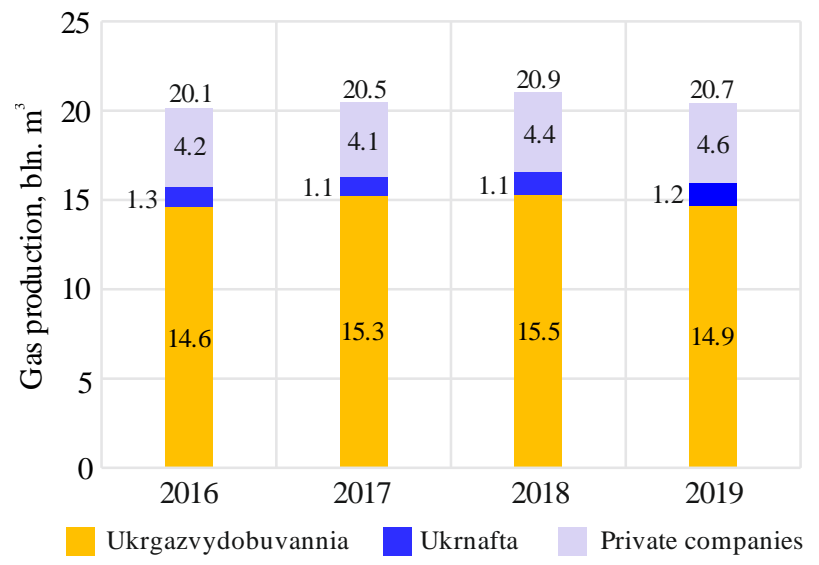

Figure 1. Structure of the gross production of natural gas in Ukraine in 2016-2019.

Given the fact that the natural gas produced by Ukrainian companies is not enough for the state to meet its own needs, the import of natural gas is necessary. For example, in 2019, Ukraine ranked 8th among European countries in terms of gas volumes imported exclusively from the European market, with total gas imports increasing by $34.5 \%$ in comparison to 2018-from 10.6 billion $\mathrm{m}^{3}$ to 14.2 billion $\mathrm{m}^{3}$ [31]. Figure 2 shows a diagram of the natural gas imported to Ukraine over the past five years.

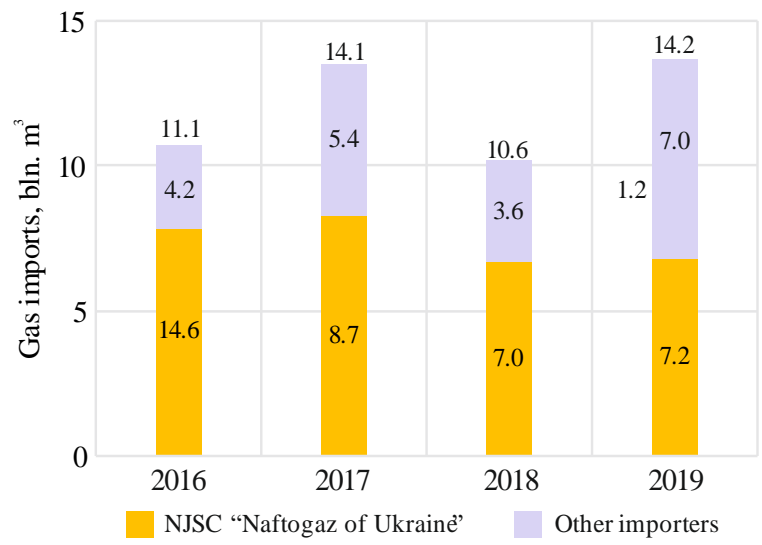

Figure 2. Volumes of natural gas imported to Ukraine in 2016-2019.

In 2019, the national company Naftogaz imported 7.2 billion $\mathrm{m}^{3}$ of gas, which is $2.4 \%$ or 0.2 billion $\mathrm{m}^{3}$ more than in 2018. In 2019, gas was mainly supplied to Ukraine via the 
Slovak route. The share of supplies through Slovakia increased from $61 \%$ in 2018 to $64 \%$ in 2019, whereas the flows from Hungary decreased from 32\% in 2018 to $26 \%$ in 2019 [32-35].

In 2019, European countries used almost 529 billion $\mathrm{m}^{3}$ of natural gas, which is $3.6 \%$ more than the total used in 2018. Ukraine ranked 7th among European countries in terms of gas consumption. The largest volumes of natural gas were consumed in the central and southern parts of the country. This high level of consumption is caused by the significant concentration of the country's industrial production capacities of mining and metallurgical and fuel and energy complexes in this region, as well as the high population in comparison with other regions. The natural gas consumptions of European countries in 2019 and Ukraine's position within this group are shown in Figure 3.

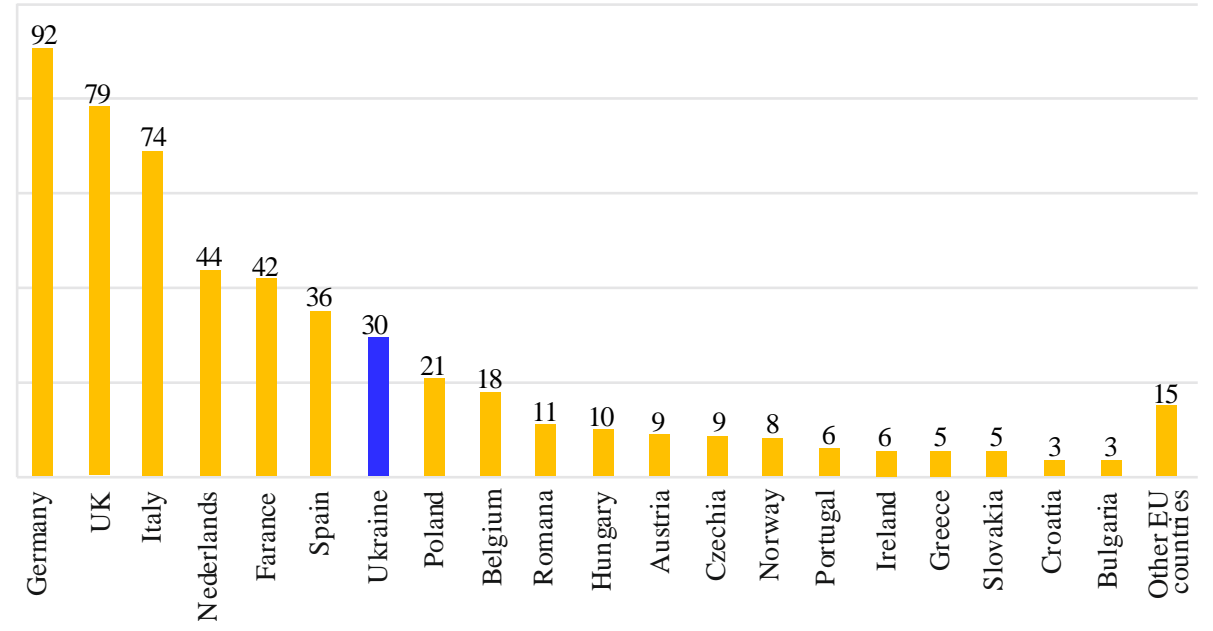

Figure 3. Volumes of natural gas consumption by European countries (billion $\mathrm{m}^{3}$ ) in 2019.

In recent years, significant changes have been occurring in the global energy market, which are caused, primarily, by the constantly increasing needs of society for energy due to economic and technological development. Leading countries are beginning to assert their right to develop energy resources in the neutral Arctic and Antarctic areas [36,37]. Stricter environmental regulations are encouraging countries to make the changeover to cleaner fuels. There is a need to search for new alternative energy sources and develop technologies for their extraction and use, as well as to increase the efficiency of existing technologies in the energy sector. Thus, ensuring energy security is becoming an increasingly complex and multifaceted task.

Despite the significant potential of the main types of renewable energy sources, their practical use today contributes only a small share in the fuel and energy balance of Ukraine [38]. However, interest in the development of technologies for producing new types of energy raw materials is significantly increasing, the most promising of which, according to the authors, are gas hydrates of the Black Sea sedimentary stratum [39-41].

Gas hydrates are crystalline compounds formed by water and natural gas molecules between which chemical bonds are not formed. Instead, the stabilization of water clathrate scaffolds is ensured by Van Der Waals bonds [42,43]. The gas hydrate properties are very unique. One volume of water, when changing to the hydrate state, binds up to 200 volumes of methane. At the same time, the fraction of gas accounts for $0.2 \mathrm{~m}^{3}$, for water $-0.8 \mathrm{~m}^{3}[44,45]$. The formation and stable existence of gas hydrates occurs under the following conditions:

- Where an appropriate combination of temperature and pressure are present: as a rule, the formation of gas hydrates occurs under conditions of rather low temperature and rather high pressure;

- A gas hydrate-forming agent must be available: methane, ethane, propane, carbon dioxide, or any other gas capable of hydrate formation. 
A shift in the phase stability of gas hydrates occurs with a decrease in pressure or an increase in temperature, which leads to the destruction of the crystalline lattice with the subsequent hydrate dissociation and gas release [46]. It is also important to note that the dissociation of the gas hydrate accompanied with a phase transformation is an endothermic process [47].

The Black Sea offshore area is characterized by the occurrence of gas hydrate deposits, the thickness of which, according to geologists and seismic exploration results, reaches an average of 500-700 $\mathrm{m}$ from the seabed surface. Gas resources that can be recovered from gas hydrate fields located directly opposite the Crimean Peninsula are assessed by scientists to be in the range of 20-25 trillion $\mathrm{m}^{3}$ [48-50].

Previous studies have revealed $[51,52]$ that gas hydrate deposits within the Black Sea bottom occur not only in the form of pure hydrate reservoirs, but often with rock intercalation, which makes the deposit structure heterogeneous. Notwithstanding that most experts argue that the "gas hydrate era" will come no earlier than in the next 10-20 years, it is already becoming necessary to develop technologies and clarify the rational parameters for the process of their development and gas recovery to ensure the energy independence of Ukraine.

\subsection{Current Status of Gas Hydrates Study}

Today, there is no industrial-scale methane production from gas hydrate deposits in the world [53-56]. However, a number of leading countries, such as Japan, the USA, Canada, India, China, Norway, South Korea, Australia, Turkey, Bulgaria, and Ukraine are involved in the implementation of large-scale research programs and are actively studying the issue of gas hydrates, both artificial and natural, as well as developing technologies for hydrate formation and dissociation [57-61].

Assessments of the economic efficiency of gas hydrate projects require the accumulation of information and clarifications [62]. This uncertainty is amplified due to the continuing search for both the optimal technologies of gas hydrate field development $[63,64]$ and gas hydrate production for use in the transportation of raw hydrocarbons $[65,66]$.

Countries with limited traditional hydrocarbon resources, such as Japan, China, India, and Korea, are the leaders in research on efficient technologies of development [67-69]. Japanese and Indian governments have established their national programs of research into marine gas hydrates [70,71]. Malaysia, Norway, Vietnam, and Mexico are among the countries which are considering government support for such programs or have recently started their implementation.

In recent years, the countries of the European Union, which have two funded research programs, namely Techniques for the Quantification of Methane Hydrate in European Continental Margins (HYDRATECH) [72] and the Geological Assessment of Gas Hydrates in the Mediterranean Sea [73], have shown significant interest in research on natural gas hydrates. According to the results of geophysical studies, signs of gas hydrate accumulations have been identified off the coast of Norway [74].

Currently, the United States continues to explore and develop technologies for producing gas from gas hydrate deposits on the northern slope of Alaska, where hydrate gas reserves, according to preliminary estimates, amount to about 16 trillion $\mathrm{m}^{3}[75,76]$. In addition, according to scientists, the reserves of gas-hydrate gas in the Gulf of Mexico may reach astronomical figures - 600 trillion $\mathrm{m}^{3}$ [77]. At the same time, as indicated in [78], gas hydrate reserves in the Green Canyon area, Gulf of Mexico reach $~ 3256 \mathrm{Mt}$, which would amount to 700 trillion $\mathrm{m}^{3}$ at standard temperature and pressure conditions.

Japanese specialists and scientists have performed large-scale seismic surveys in the Pacific Ocean in the Nankai Trough $[79,80]$. When drilling, three thick hydrate reservoirs have been revealed. Preliminary estimates have shown that the field contains up to 60 trillion $\mathrm{m}^{3}$ of methane [81].

Analysis of thermobaric conditions within the deep-water area of the Black Sea Depression gives reason to assert that the existing temperature and pressure parameters at 
sea depths of 400-700 $\mathrm{m}$ are optimal for the formation of gas hydrate deposits under such conditions $[48,82]$. The lower limit of these deposits existence is $700 \mathrm{~m}$ under the seabed and depends on the sea depth.

There are three main methods for recovering gas from gas hydrates: the thermal method, based on heating the deposit; the depressurization method, which is aimed at reducing the pressure in the gas hydrate; and the method of replacing or adding chemical substances, which are catalysts for the dissociation process of a gas hydrate deposit [83-87].

In [88], two methods of gas recovery from gas hydrates are studied: depressurization (the method of decreasing the pressure) and the introduction of inhibitors. The methane hydrate characteristics have been determined in the process of their dissociation. The dependence of the gas hydrate dissociation rate on the velocity and temperature of brine injection, pressure, and the area of the hydrate (brine surface) is presented. Depressurization experiments have revealed that the dissociation of the hydrates leads to a drop in the rate of pressure reduction and significantly (from 15\% to 70\%) contributes to the produced gas accumulation.

Chemical inhibitors as potential allies for $\mathrm{CO}_{2}$ replacement in gas hydrate reservoirs are studied in [89] and the possibility of increasing the $\mathrm{CO}_{2}$ replacement process efficiency by exploiting sodium chloride properties is considered.

In [90], the effect of gas hydrate self-preservation during dissociation under various temperatures and pressures is studied. The authors carried out laboratory experiments on the dissociation of methane hydrates in order to use this method in the development of gas hydrate deposit and natural gas recovery. The studied gas hydrates have been obtained for the first time by experimentation with methane gas. Methane gas hydrate dissociation was studied under atmospheric pressure in the temperature range of -7 to $+5^{\circ} \mathrm{C}$.

In [91], the possibility of the formation of hydrates from $\mathrm{CO}_{2}$ is studied. The principle of replacing $\mathrm{CH}_{4}$ with $\mathrm{CO}_{2}$ when extracting natural gas from gas hydrate deposits is considered. The case of preserving $\mathrm{CO}_{2}$ in the deep-water sea area by displacing the natural gas from a hydrate field is analyzed using the example of the Bay of Biscay.

In [92] the specificity of drilling wells with the use of structural equipment during liquid hydrocarbon extraction, including the development of gas hydrate fields, is discussed. Attention is focused on performing certain operations, such as cementing, perforations, sand screen or gravel packing, and inserting well completion strings during the process completing gas hydrate wells and equipping them with additional infrastructure.

Modeling the process of gas hydrate dissociation whilst accounting for the peculiarities of a reservoir's geological structure when using the depressurization method is studied in [93]. The authors found that gas should be recovered from a hydrate deposit with account of the existing interbedded water in the reservoir.

In [94], the thermodynamic and dynamic processes occurring during the dissociation of gas hydrates are studied. Methods and methodology for research on hydrate dissociation from both a macroscopic and microscopic point of view have been determined and described. Experimental studies, taking into account macroscopic peculiarities, are mostly focused on laboratory devices and a technical approach to the gas hydrate dissociation of various gases in a vacuum. Microscopic studies make it possible to visually observe the gas hydrate dissociation using nuclear magnetic resonance tomography, in order to study the micromechanisms of hydrate dissociation.

In [95], an analytical review is provided of the current state of gas hydrates research abroad and directly in the Black Sea. It is indicated that in the deep-water area of the Black Sea the necessary conditions for the accumulation of gas hydrates are present. The continental slope of the north-western Black Sea shelf is of particular interest, where gas hydrate accumulation is confirmed by seismic signs. The Black Sea region, due to the distribution of organically rich facies in Maykop [96], is potentially hosting large hydrate deposits.

Given the available energy potential of gas hydrates and the possibility of using hydrate gas as an additional energy carrier, it is evident that the development and search 
for specific technological solutions for the rational recovery of methane from gas hydrate deposits is of acute concern for Ukraine and requires an urgent solution.

The existing technological solutions for methane gas recovery from gas hydrate deposits in the Black Sea, containing bottom rock intercalation, have not been sufficiently studied. Scientific substantiation of the dissociation zone of a gas hydrate deposit is an important stage in the technology of its development, namely, clarifying the distance between wells and predicting the volume of gas that can be extracted from the well.

\subsection{Conditions of Gas Hydrate Deposit Occurrence in the Black Sea}

Based on the results of seismic and geoacoustic surveys in the Black Sea, anomalies (such as bottom-simulating reflector (BSR), and velocity-amplitude anomalies (VAMPs)) have been distinguished, which indicate the occurrence of gas hydrates. Such areas are known to exist in the west of the Black Sea Depression, the Barrier anticlinal zone, on the Palas Rise, in the Sorokin Trough, on the Anapa ledge, and at the foot of the Caucasian continental slope. In the Black Sea, more than ten areas where there is an occurrence of gas hydrates have been recorded in the near-surface layer of sediments in the range of 0.60 to $2.85 \mathrm{~m}$ (on the Crimean continental slope, on the Palas Rise, etc.).

In some of the Black Sea areas at depths of 700-1350 m [97,98], gas hydrate deposits of methane with a thickness of 400-500 $\mathrm{m}[48,99]$ under the sea floor have been identified. At the same time, as indicated in the research paper [48], based on seismic surveys, gas hydrates are formed starting from a water depth of 700-750 m for pure methane and $300-500 \mathrm{~m}$ for natural gas with a specific gravity of 0.6.

The lower limit of the methane hydrate occurrence depends on the water depth and the thermal gradient value in the sediments. The composition of the hydrate-forming gas, bottom temperature, and salinity, as well as the salinity of sediment pore-water, definitely have an influence on the gas hydrate stability zone $[100,101]$.

The Black Sea sediments, ranging mainly from depths of 0 to $700 \mathrm{~m}$, are gassed with methane. In [102] the noted value range was between 35-835 $\mathrm{m}$, in [103] the depth marked was $140-725 \mathrm{~m}$. Powerful gas emissions in the form of numerous seepages, fountains, and mud volcanoes have been recorded along almost the entire Black Sea perimeter. Currently, about 4000 gas flares have been identified in the Black Sea, localized along the periphery, in particular, in the north-west of the Black Sea in the Bulgarian and Kerch-Taman shelves, along the Caucasus coast, and on the continental slope and shelf of Turkey [104]. The generalized map that describes the Black Sea floor degassing is presented in Figure 4 [105].

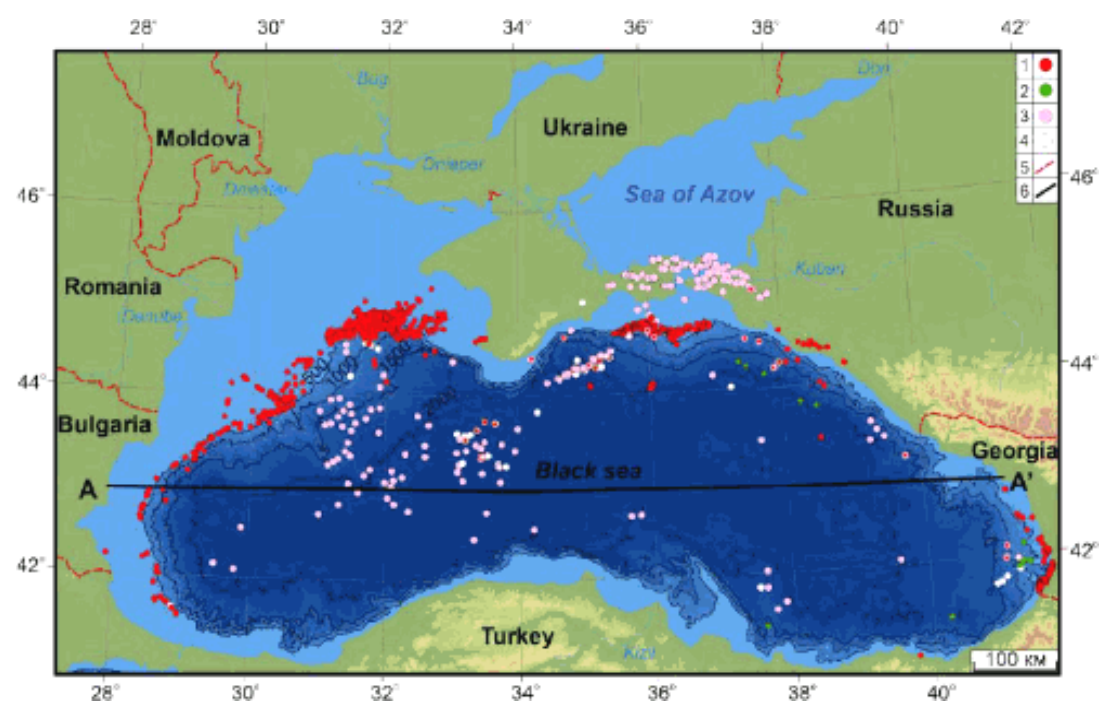

Figure 4. Seafloor degassing in the Black and Azov seas. 1: gas seep locations; 2: oil seep locations; 3: submarine mud volcanoes; 4 : gas hydrates; 5 : state borders; 6 : location of the section of suitable temperature and water salinity [105]. 
It is known that the conditions required for the formation and existence of gas hydrates are the presence of necessary pressures and temperatures, as well as a sufficient amount of water and free gas (or gas dissolved in water). Gases at appropriate temperature and pressure parameters, when combined with water, form a zone of gas hydrate accumulation. The parameters of this zone in the Black Sea and other seas directly depend on gas saturation, gas composition, and water mineralization $[85,106,107]$. Thus, the presence of heavy hydrocarbons and carbon dioxide increases the temperature of hydrate formation, and water salinity reduces it [108].

The performed theoretical calculations of the depth of occurrence and thickness of the hydrate formation zone evidences that in most of the Black Sea Depression there is a favorable thermobaric environment for the formation and stable existence of gas hydrate deposits $[97,109]$. Pressure and temperature parameters are extremely important and necessary; however, the sources and mechanisms of gas hydrate deposit formation are also of great importance during hydrate formation [110].

The phase equilibrium of gas hydrates is dependent on temperature changes. At a pressure gradient of $1-2 \mathrm{MPa} / \mathrm{K}$, a temperature change of $1{ }^{\circ} \mathrm{C}$ is accompanied by a change in the hydrate layer thickness of between $50-100 \mathrm{~m}$. Therefore, when assessing the boundary position and thickness of the hydrate formation zone, the most insignificant temperature variations (including temperature variations over time) should be taken into account, which are conditioned by the changes in bottom temperature, heat exchange conditions in the bottom water layer, sediment accumulation, etc. [95].

The continuous process of deposit formation leads to a decrease in heat flow in the upper part of the sedimentary stratum and its increase in the lower part of the stratum. Isotherms, when shifting gradually upward, should contribute to the gas hydrate deposit destruction from below and its growth in the upper part. The hydrates destruction is accompanied by heat absorption $\left(400-600 \mathrm{~kJ} / \mathrm{kg}\right.$ in the range of $\left.0-20^{\circ} \mathrm{C}\right)$, and the hydrates formation is accompanied by its release $[95,111]$.

The Ukrainian part of the sea possesses methane gas resources of about of 20-25 trillion $\mathrm{m}^{3}$, which can be extracted from gas hydrate fields located directly opposite the Crimean Peninsula [112]. The total predicted gas resources in the entire Black Sea are no less than 100 trillion $\mathrm{m}^{3}$, based on the results of drilling and the analysis of the studied cores $(1988-1989)[48,49]$. It is noted in $[96,113]$ that in addition to enormous gas reserves, the Black Sea (in the western Black Sea sub-basin part) hosts large amount of organic matter, which is converted into petroleum components such as oil and gas. It is one of the largest underexplored petroleum-bearing basins in Europe.

In the process of research aimed at studying the heat flow distribution in the Black Sea Depression, A.D. Duchkov and S.A. Kazantsev [114] have identified a wide and extended zone of reduced (by almost twice) heat flow, extending across the entire offshore area from west to east, and a similar anomaly in the northern part of the Black Sea, opposite the Kerch Strait.

In 1996, gas hydrates were also found in the Sorokin Trough and the central part of the Black Sea $[115,116]$. The generalized data on the conditions for the formation and existence of gas hydrates, based on the available results of analysis of cores from the drilled wells, lead to the conclusion that gas hydrates are accumulated in the Black Sea sediments at appropriate temperature and pressure parameters. These parameters satisfy the conditions of the stable existence of gas hydrate deposits not only in the form of pure hydrate reservoirs, but, often, with rock aluminosilicate intercalation, which makes the structure of the deposit heterogeneous $[117,118]$.

Some gas hydrates contain up to $90-97 \%$ methane. The performed studies have shown the presence of not only hydrocarbon gases in gas hydrate deposits, but also nitrogen, carbon-dioxide, and hydrogen sulfide, but their amount is insignificant [119]. At the same time, even insignificant admixtures of the above-mentioned substances strongly affect the thermobaric conditions of gas hydrate formation and stability [120-123]. 


\subsection{Aim of the Research}

Given the enormous gas reserves that are accumulated in the Black Sea sediments in a hydrate state, and the prospects for the development of gas hydrate deposits as an alternative source of energy, it is necessary to study the issues and conduct research related to substantiating the parameters of an effective dissociation process of deposits with a heterogeneous structure and the recovery of methane gas from them.

To achieve this aim, the following research objectives are formulated:

1. Obtain and form gas hydrate deposits in the tank of a laboratory setup, taking into account the variable share of rock intercalation: a pure gas hydrate with a $0 \%$ intercalation share and gas hydrates of a heterogeneous structure with 15, 30, 45 and $60 \%$ intercalation shares, respectively.

2. Study the dissociation process of the formed gas hydrate deposits with the corresponding share of rock intercalation (from 0 to $60 \%$ ).

3. Determine the volumes of methane gas released during the dissociation of each specific deposit with the corresponding share of rock intercalation (from 0 to $60 \%$ ).

4. Determine the formed zone volumes of the gas hydrate deposit dissociation with the corresponding share of rock intercalation contained in them using the computer modeling with the Surfer-8.0 software product.

\section{Materials and Methods}

\subsection{Experimental Study}

Obtaining gas hydrates is the first stage of research, the purpose of which is to create samples of pure gas hydrates and gas hydrates with a variable share of rock aluminosilicate intercalation from marine sediments (heterogeneous structure). In general, the laboratory research procedure of the first stage includes preparing the samples for physical modeling, conducting a series of experiments, and processing the obtained experimental data. As a result of laboratory research, the authors have revealed the dependence of hydrate accumulation on the time of the hydrate formation process at variable thermobaric parameters [65]. It has been determined that the maximum rate of pure gas hydrate formation, which does not contain rock intercalation, is the rate at $T=+1^{\circ} \mathrm{C}$ and $P=10 \mathrm{MPa}$. The percentage of hydrate accumulation changes according to the polynomial dependence with the approximation accuracy of $R^{2}=0.99$.

The second stage of research, the results of which are presented below, is the determination of the dissociation process parameters of the obtained gas hydrate deposits with heterogeneous structures, as well as the regularities of the methane gas recovery depending on the content of rock intercalation.

The research on the dissociation process is as follows: a laboratory setup for studying the dissociation process is filled with the previously obtained gas hydrate (Figure 5).

Since the amount of methane hydrate which is required to fill the tank cannot be obtained at once, but only after several hydrate formation cycles, the pre-formed hydrate was first conserved in a freezer at $-15^{\circ} \mathrm{C}$ until the required amount was completely obtained, and only after that was the tank of the laboratory setup filled with a hydrate mass.

It has been determined through research that gas hydrates undergo a process of self-preservation through their slow dissociation (and in some cases almost complete cessation of dissociation) of methane hydrates and other gases when the ambient pressure decreases below the pressure of the three-phase equilibrium "gas-ice-hydrate" under freezing temperatures due to the formation of an ice film on the gas hydrate surface. In particular, natural gas hydrates are stable at atmospheric pressure and temperatures close to $-15{ }^{\circ} \mathrm{C}$. This phenomenon gives grounds for considering the possibility of transporting gas in hydrated form at atmospheric pressure and freezing temperatures. This method of storing and transporting gas hydrate has been studied extensively by leading scientists in England, Norway, and Japan [124]. The self-preservation effect is explained by the fact that at the initial stage of dissociation the hydrate is covered with a surface ice film, which prevents or even completely slows down its further dissociation $[125,126]$. Thus, the 
possibility of the long-term storage of gas hydrate samples in a metastable thermodynamic state is revealed.

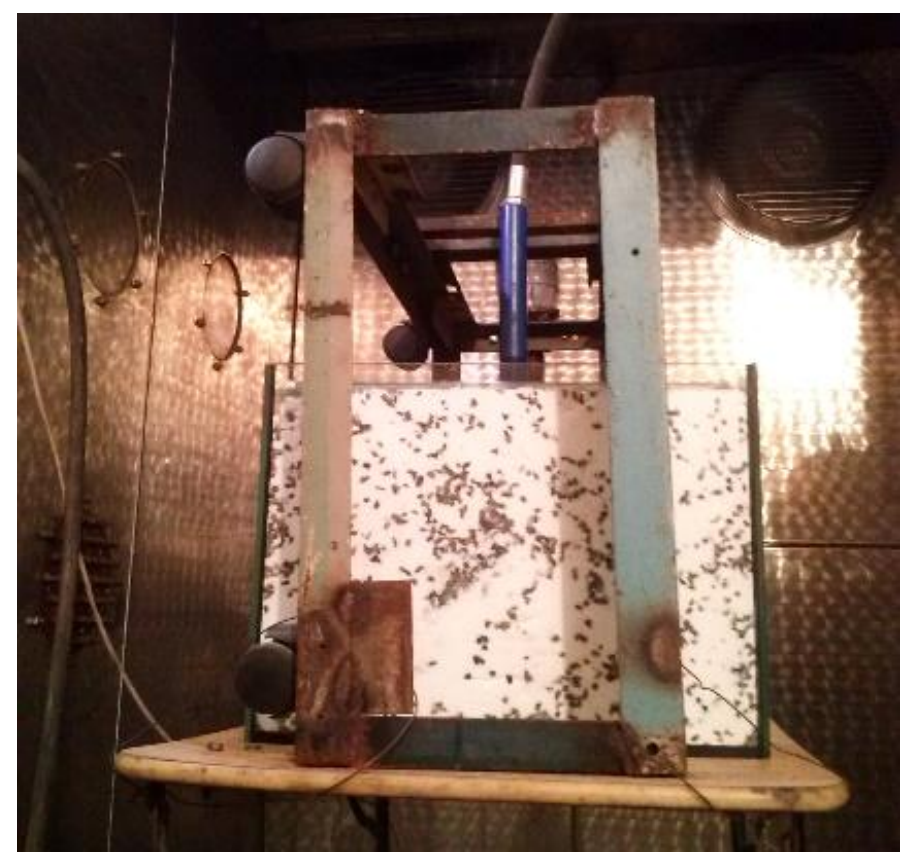

Figure 5. The tank used for modeling gas hydrate deposits and studying the gas hydrate dissociation zone.

To fill the tank with both pure gas hydrates and gas hydrates with a variable share of rock intercalation from 15 to $60 \%$ (at increments of $15 \%$ ), it is necessary to carry out 12 cycles of the hydrate formation process.

The tank is made of glass, has the dimensions $40 \times 30 \times 40 \mathrm{~cm}(W \times H \times L)$, and allows us to visually observe the course of the research process. The tank volume is $0.048 \mathrm{~m}^{3}$. The required scale factor is set based on the tanks geometrical dimensions for studying the gas hydrate dissociation process and is determined by Equation (1):

$$
x=\frac{W_{n}}{W_{m}}=\frac{H_{n}}{H_{m}}=\frac{L_{n}}{L_{m}}, \text { and is } x=100
$$

where $W_{n}, H_{n}$, and $L_{n}$ are width, height, and length in real size; $W_{m}, H_{\mathrm{m}}$, and $L_{m}$ are width, height, and length for the model.

Based on this, the volume of gas hydrate deposit in natural conditions is $48,000 \mathrm{~m}^{3}$.

When the tank is two-thirds filled with hydrate mass, pipes are lowered into it, simulating a pipeline system for pumping a heat-transfer agent and subsequent methane production. Then, the hydrate continues to accumulate in the tank to form gas hydrate deposits until the tank is completely filled. To isolate gas hydrate after filling the tank, it is covered with a lid made of organic glass, which contains an opening inside for the exit of the pipes lowered into the tank.

The well diameter, based on the specified standard sizes, in full-scale conditions is $0.14 \mathrm{~m}$. If to take into account the scale factor, then in laboratory conditions it should be equal to $1.4 \times 10^{-3} \mathrm{~m}$, which is impossible. Therefore, a steel pipe is chosen with a diameter of $3.5 \mathrm{~cm}$. Having analyzed the diameters of these pipes, it can be seen that the required laboratory diameter exceeds the accepted diameter by 25 times. This means that the time required for dissociation of the total volume of gas hydrate deposit relative to real conditions should be 25 times less than that obtained under laboratory conditions. The tank is filled with hydrate mass directly in the climatic thermal chamber while maintaining the temperature of $-15^{\circ} \mathrm{C}$ to ensure the effect of gas hydrate self-preservation [127]. 
The next stage of the research is to pump a heat-transfer agent with a temperature of $+12{ }^{\circ} \mathrm{C}$ through a funnel mounted on the inner pipeline. The heat-transfer agent is supplied once with the subsequent dissociation zone determination. The minimum heattransfer agent volume required for the gas hydrate dissociation is calculated based on Mendeleev-Clapeyron's law:

$$
P V=n R T
$$

where $P$ is pressure, atm; $V$ is molar volume, $\mathrm{m}^{3} ; R$ is absolute gas constant, $R=8.31 \mathrm{~J} / \mathrm{mol} \cdot \mathrm{K}$; $T$ is temperature, $\mathrm{K} ; n$ is number of moles in a substance. From this equation, it follows that the number of moles of gas hydrate in the tank of a laboratory setup can be calculated as follows:

$$
n=\frac{P V}{R T}
$$

making 2.2 moles.

It should be taken into account that the molar heat capacity of the hydrate $Q$ is $57.7 \mathrm{~kJ} / \mathrm{mol}$. Hence, the expected (based on the provided calculation) internal energy of the gas hydrate in the tank is $126.9 \mathrm{~kJ} / \mathrm{mol}$. Knowing that $Q=c \cdot m \cdot \Delta T$, where $c$ is heat capacity of the heat-transfer agent at $+12{ }^{\circ} \mathrm{C} \mathrm{kJ} / \mathrm{kg} \cdot \mathrm{K} ; m$ is heat-transfer agent mass, $\mathrm{kg} ; \Delta T$ is temperature difference, ${ }^{\circ} \mathrm{C}$, then $\mathrm{m}=Q / \mathrm{c} \cdot \Delta T=2.5 \mathrm{~kg}$. Thus, the amount of heat-transfer agent that must be supplied to the tank is $2.3 \mathrm{~L}$.

Gas hydrate dissociation is a heterogeneous process, since it occurs at the interphase boundary of the solid phase (outgoing gas hydrate) and a mixture including liquid and gas. The dissociation is a topochemical process, which is accompanied by the disappearance of one phase due to the changeover of hydrate ice to its more fragile structure and, finally, the formation of new phases. For the effective course of the dissociation process, a shift is necessary in thermobaric parameters of the stable existence of the gas hydrates. That is why, as a solvent, a heat-transfer agent is supplied in order to shift the equilibrium state in the system.

The volume of the heat-transfer agent is calculated empirically, based on the known values of the gas hydrate heat capacity. The value of $2.3 \mathrm{~L}$ is the optimal volume, which contributes to the sequential dissociation of the obtained gas hydrate samples and makes it possible to study the course of the process. A larger volume of heat-transfer agent would lead to a sharp dissociation, and a smaller amount would not allow the process to start.

The dissociation process onset is initiated by a certain number of voids formed in the hydrated ice, sufficient for the actual rearrangement of its structure. This is certainly related to the presence of a necessary energy supply, due to which the gas molecules are separated from the water molecules. Therefore, exactly $2.3 \mathrm{~L}$ are fed into the tank once, and then the dissociation process is visually observed, since it has been determined by calculations that this volume of the heat-transfer agent at a temperature of $12{ }^{\circ} \mathrm{C}$ is sufficient to dissociate the formed volume of gas hydrates in the tank of the laboratory setup.

These stages for the formation and filling of the tank with a hydrate mass are carried out for each type of gas hydrate deposit, depending on the amount of rock intercalation, which are laid at the beginning of the experiment in the hydrate formation reactor. Figure 6 schematically shows the course of the dissociation process of the formed gas hydrate deposit, which occurs as follows: with the gas hydrate formed at the previous research stage (3), which contains a certain amount of rock intercalation (4), a glass tank (1) of a laboratory setup is filled to determine the dissociation zone. 


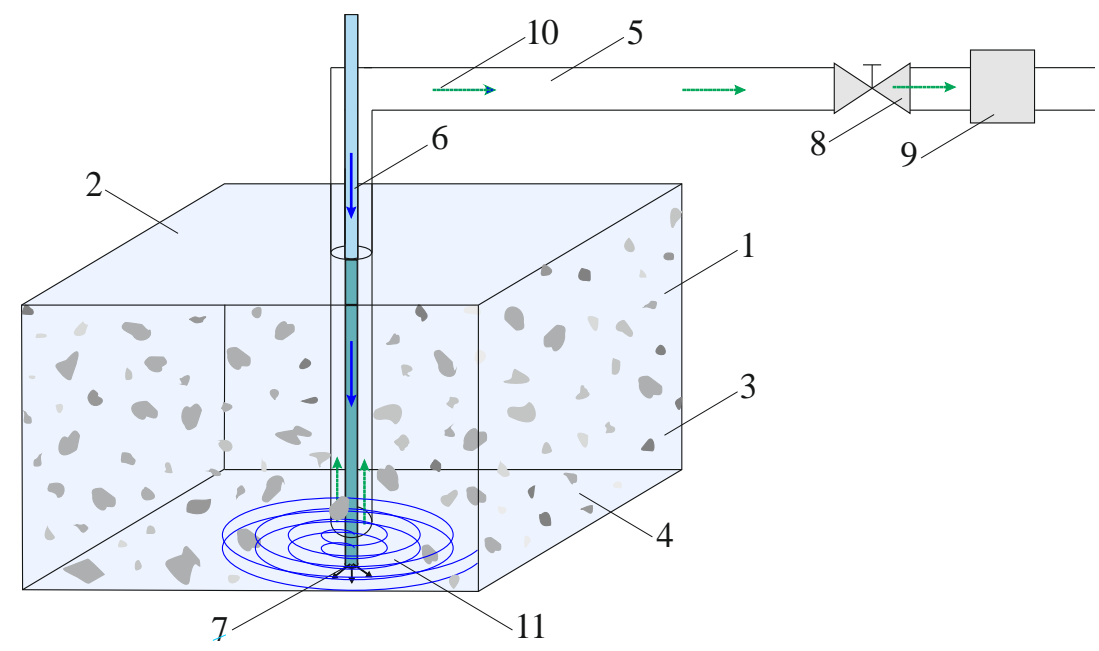

Figure 6. Scheme for the research on gas hydrate dissociation. 1: glass tank; 2: lid of the tank; 3: formed gas hydrate deposit; 4: rock intercalation; 5: outer pipeline; 6 : inner pipeline; 7: outlet of the heat-transfer agent; 8: tap; 9: gas meter; 10: gas outlet; 11: pumping of a heat-transfer agent; 12: dissociation zone.

After the tank (1) is filled, it is covered with a lid (2) made of organic glass, which contains a hole in the middle for placing the outer (5) and inner (6) pipelines, simulated by pipes. A heat-transfer agent (11) in the form of water with a temperature of $+12{ }^{\circ} \mathrm{C}$ is supplied through the inner pipeline (6). The gas hydrate deposit dissociation occurs from the bottom up and the supplied water spreads in the lower part of the hydrate (7), thereby causing its further dissociation and the release of methane (10), which outflows through an external pipeline (5). The volume of the methane evolved is measured with a gas meter (9) set at the end of the outer pipeline. The dissociation zone formed is a subject for further research in order to determine the dissociation radius of both pure gas hydrate deposits and deposits with a heterogeneous structure.

Without doubt, the radius, and consequently the dissociation zone, depend on the amount of supplied heat-transfer agent. With a large-scale increase or decrease in the geometric parameters of the laboratory tank for the normal course of the reaction, including even for its beginning, it is necessary to supply the minimum volume of the heat-transfer agent sufficient to start the dissociation process, calculated on the basis of the MendeleevClapeyron's law [104].

The gas hydrate dissociation, which is similar to any other heterogeneous process, occurs at the interphase boundary and contains several sequential stages. Its ultimate goal is the complete recovery of methane gas and the separation of water and rock intercalations, if the latter are present in the deposit. When conducting this research, which is based on a large number of preliminary experimental studies, we tried to obtain the optimal parameters of the heat-transfer agent and, most importantly, to experimentally confirm the stability of the dissociation process depending on the number of rock intercalations in laboratory conditions. Moreover, the main factor is precisely the dissociation process stability of the deposit, since an excess of the heat-transfer agent or an increase in its temperature creates an uncontrolled process of gas release and on an industrial scale can have dangerous and harmful consequences [128-133].

\subsection{Quantitative Study of Dissociated Gas}

The volume of methane gas that can be obtained during the dissociation of $1 \mathrm{~m}^{3}$ of gas hydrate deposit, depending on the share of rock intercalation contained in it, is determined in two ways. The analytical and laboratory studies of the dissociation process should be performed five times taking into account the studied type of gas hydrates: pure gas hydrates and gas hydrates with heterogeneous structures with 15, 30, 45 and $60 \%$ shares of intercalation. 
Analytically, the volume of methane is determined by the following Equation (4):

$$
V_{C H_{4}}^{a n}=\left(V_{\text {g.h.d. }}^{a n}-V_{\text {g.h.d. }}^{a n} \cdot \frac{\eta_{\text {in }}^{a n}}{100}\right) \cdot V_{\text {const }}, \mathrm{m}^{3}
$$

where $V_{g . h . d .}^{a n}$ is the volume of the gas hydrate deposit in $1 \mathrm{~m}^{3} ; \eta_{i n}^{a n}$ is the rock intercalation share, $\%$; $V_{\text {const }}$ is the constant of methane gas output from $1 \mathrm{~m}^{3}$ of gas hydrate, $\mathrm{m}^{3}$.

The dissociation zone volumes of gas hydrate deposits for $1 \mathrm{~m}^{3}$ are recalculated using Equation (5):

$$
V_{C H_{4}}^{l a b}=\left(\frac{V_{g . h . d .}^{a n}}{V_{\text {g.h.d. }}^{\text {lab }}}-\frac{V_{g . h . d .}^{a n}}{V_{\text {g.h.d. }}^{\text {lab }}} \cdot \frac{\eta_{\text {in }}^{l a b}}{100}\right) \cdot V_{l a b}, \mathrm{~m}^{3}
$$

where $V_{g . h . d .}^{a n}$ is volume of the gas hydrate deposit in $1 \mathrm{~m}^{3} ; V_{g . h . d}^{\text {lab }}$ is the dissociation zone volume of gas hydrate deposit, $\mathrm{m}^{3} ; \eta_{i n}^{\text {lab }}$ is the rock intercalation share used during the laboratory research, \%; $V_{\text {lab }}$ is the volume of gas obtained during the research, $\mathrm{m}^{3}$.

\subsection{Study of the Dissociation Process}

The propagation of the dissociation zone during the development of gas hydrate deposits depends on mining and geological conditions of their occurrence, among which the rock intercalation share is the most important, since it is this that determines the sharp variability of the gas hydrate properties. Therefore, the probability of predicting the dissociation zone depends on the completeness of using the data accumulated during the research, their generalization, and analysis. To determine the dissociation zone, data on the geometric parameters of the tank in the laboratory setup are required. Currently, the mathematical apparatus of the approximation theory is most often used in practice, which allows for the description of any geometric surfaces [134]. In our case, this is the final dissociation zone of the gas hydrate deposit (where the walls of the dissociation zone are in contact with the gas hydrate).

It is known from the approximation theory [135] that almost any surface specified by coordinate points can be represented by isolines and defined as the geometric locus of coordinate point intersections which satisfy Equation (6):

$$
z=f(x, y)
$$

where $z$ is value at ith point; $f$ is some approximating function; $x, y$ are coordinates in any coordinate system.

As practice shows, the above function cannot be found numerically due to the complexity of the studied surfaces, but it can be approximated and roughly represented by the known Equation (7):

$$
z=f(x, y)+\varepsilon
$$

where $\varepsilon$ is a remainder that cannot be approximated.

The existing function $f(x, y)$ can be expanded in a series in the form:

$$
f(x, y)=f_{1}(x, y)+f_{2}(x, y)+\ldots+f_{k}(x, y),
$$

The numerical function components $f_{k}(x, y)$ are permanently in numerical form under the condition that the squares of the numerical deviations of the approximating surface from the original one is minimal. The sum of the squares of the actual surface numerical deviations from the calculated one, which is calculated at the specified points, must be minimal $\left(\sum \varepsilon_{I}^{2}\right)$. Most often, in practice, algebraic approximations that imply the function $f(x, y)$ expansion in degrees of $x$ or $y$, or special polynomial functions, are used. Existing developments, one way or another related to the surface approximation algorithm, pursue two goals: to find the most economical and best approximation of the original surface [136]. Computer modeling makes it possible to perform the necessary approximations for surfaces of any complexity. When performing scientific research, approximations are used to 
analytically describe the surfaces of objects and bodies, as well as to perform various operations within them, such as addition, subtraction, differentiation, and integration to calculate the volumes of bodies, which are limited to known values. The most accurate methods for performing the necessary approximations are methods that allow with high accuracy the description of the existing surface of an object at any of its spatial positions. Among the computer methods for determining the volumes of spatial bodies, methods are widely applied that use the surface areas of vertical and horizontal sections as input data [137]. If the object is represented as a solid body $A C^{\prime}$ with base $A B C D$, as shown in Figure 7,

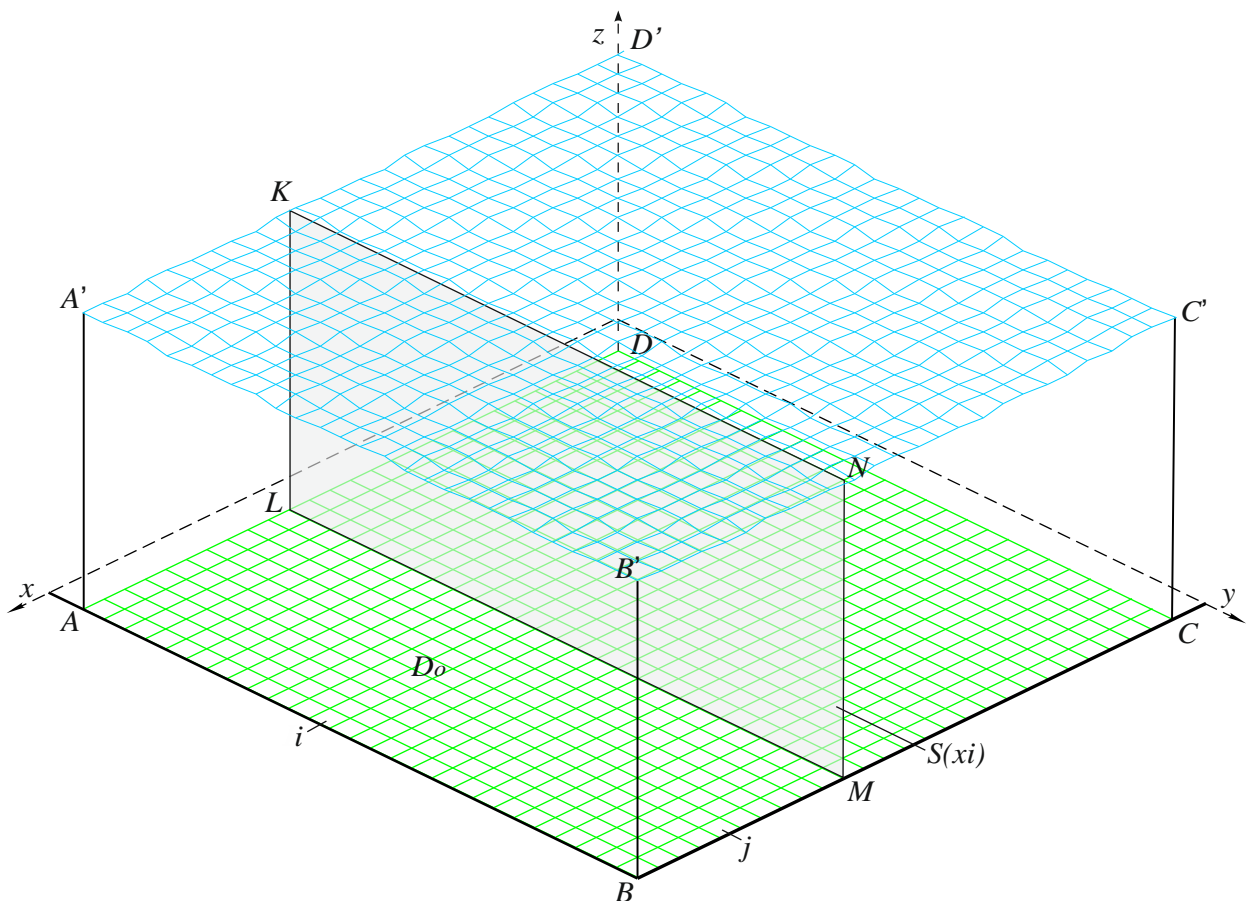

Figure 7. Scheme for computer-based volume determination.

then its volume $V$ can be expressed by a double integral [138]:

$$
V=\iint_{D_{0}} f(x, y) d x d y
$$

The same volume comes out of the variable plane $S(x)$ of the vertical section KLMN by Equation (10):

$$
V=\int_{D}^{A} S(x) d x,
$$

where $A$ and $D$ are the ranges of coordinates along the $x$ axis.

The KLMN area is determined by Equation (11):

$$
S(x)=\int_{D}^{C} z d y=\int_{D}^{C} f(x, y) d y,
$$

where $C$ and $D$ are the ranges of coordinates along the $y$ axis. 
Automatic calculation of the constructed object volume with high accuracy is determined from the area of the curvilinear trapezoid:

$$
\int_{D}^{C} f(y) d y=\frac{C-D}{n}\left(\frac{z_{0}+Z_{n}}{2}+z_{1}+z_{2}+\ldots+z_{n-1}\right),
$$

and Simpson [139]:

$$
\int_{D}^{C} f(y) d y \approx \frac{C-D}{3 n}\left(\frac{z_{0}+Z_{n}}{2}+z_{1}+z_{2}+\ldots+z_{n-1}\right)+2\left(z_{1 / 2}+z_{1 / 3}+\ldots+z_{n-1 / 2}\right) .
$$

Figure 8 shows an example of a modeling object vertical section with the indicated key parameters, which are taken into account when calculating the area and subsequent volume determination.

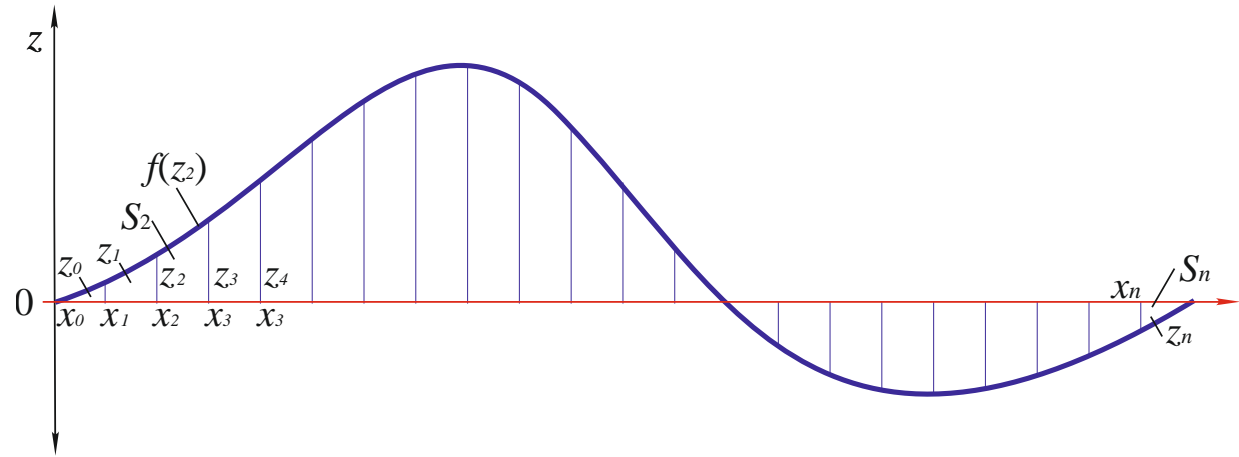

Figure 8. Scheme for determining the area of the modeling object vertical section.

The range of the approximating surface is to determine the boundaries of the maximum and minimum coordinates of observation points, which are grouped and divided into lines $j$ and columns $i$. The reliability of the determined volume depends on the value of space between the lines and columns.

The above algorithm, described on the basis of the Surfer-8.0 software, is used for the computer-based determination of the dissociation volume in the tank of a laboratory setup. This program, which is based on the data interpolation method, makes it possible to describe the boundaries of three-dimensional bodies by determining their volume with high accuracy. The method of determining intermediate values and quantities from the available discrete set of known values is a very effective way to solve such problems.

This interpolation method of geostatics, science, and technology for the analysis, processing, and presentation of spatially-distributed information is based on the generalized linear "Kriging" regression [140-142]. This kind of regression uses parameters to determine the optimal estimates in terms of the minimum root-mean-square deviations when constructing a 3D grid-visualization. The latter implies the construction of graphical data images for the possibility of their analysis and identification of anomalies with the resulting structure [134].

A significant advantage of the Surfer-8.0 software is that it is able to process three methods for calculating the volume of modeling bodies: the curvilinear trapezoid method, the Simpson method, and the Simpson's three-eighths method [134,143]. The resulting difference in values is a qualitative comparative assessment of the volume calculation accuracy. The arithmetic mean of the three results is taken as the final volume of the object. 
The relative error of the computational object is estimated by comparing the results of the three methods and is expressed as a percentage ratio from the average value [137]:

$$
1 / m=\frac{\left(V_{\max }-V_{\min }\right) \cdot 100 \%}{V_{a r}},
$$

where $1 / m$ is the relative error; $V_{\max }$ is the largest volume from the results obtained using the three methods; $V_{\min }$ is the smallest of the results; $V_{a r}$ is the arithmetic mean from the three results.

Cases where the values of the three volumes are close to each other indicate that the result obtained most likely correspond to the real object. Accordingly, to find sufficiently accurate results, it is necessary to have as many values of the coordinate grid points as possible.

\section{Result and Discussion}

The results of the analytical and experimental studies on the volumes of methane gas output during the dissociation of the gas hydrate deposits are presented in Table 1 . The convergence between the results ranges from 75 to $91 \%$.

Table 1. Gas volumes obtained during the research on the dissociation process of $1 \mathrm{~m}^{3}$ of gas hydrate deposits.

\begin{tabular}{cccccc}
\hline Rock Intercalation Share, $\%$ & 0 & 15 & 30 & 45 & 60 \\
\hline $\begin{array}{c}\text { Analytical determination of } \\
\text { methane gas volumes, } \mathrm{m}^{3}\end{array}$ & 164.0 & 139.4 & 114.8 & 90.2 & 65.6 \\
$\begin{array}{c}\text { Experimental determination of } \\
\text { methane gas volumes, } \mathrm{m}^{3}\end{array}$ & 149.7 & 103.9 & 95.7 & 73.3 & 47.3 \\
\hline
\end{tabular}

After experimental studies on the gas hydrate dissociation with the resulting methane, the tank of the laboratory setup is opened. To determine the dissociation zone parameters, a coordinate grid of points dispersed on the plane of the tank at the beginning of observations is used. With an increment of $1 \mathrm{~cm}$ from the tank surface, the spatial change in the contact points of the dissociation zone with an artificially created gas hydrate deposit is determined.

The obtained data are recorded in the record book in the form of coordinate points $x$, $y$, and $z$, where $x$ and $y$ are the length and width of the tank, respectively, and $z$ is its height. The grid files represent a network of control points with the same range of coordinate variation. Before starting the computer-based calculations, an initial data array is created of the surfaces $z_{i}=f_{i}(x, y)$ in .xls format, where $x_{i}, y_{i}$ are point coordinates and $z_{i}$ is their spatial displacement.

Using the obtained observation results of the final dissociation zone shape and the Surfer-8.0 software product, a 3D grid-visualization of the developed lower part of the gas hydrate deposit in space is constructed on the basis of the data interpolation method.

When opening the tank model, it has been revealed that the gas hydrate deposit dissociation occurs not only in the lower part of the well.

The dissociation zone parameters propagate a certain distance upwards along the well. This is conditioned by the rapid propagation of the dissociation reaction. Accordingly, it is evident that when determining the dissociation zone volume, it is necessary to construct a model consisting of two spatial figures (Figure 9). 


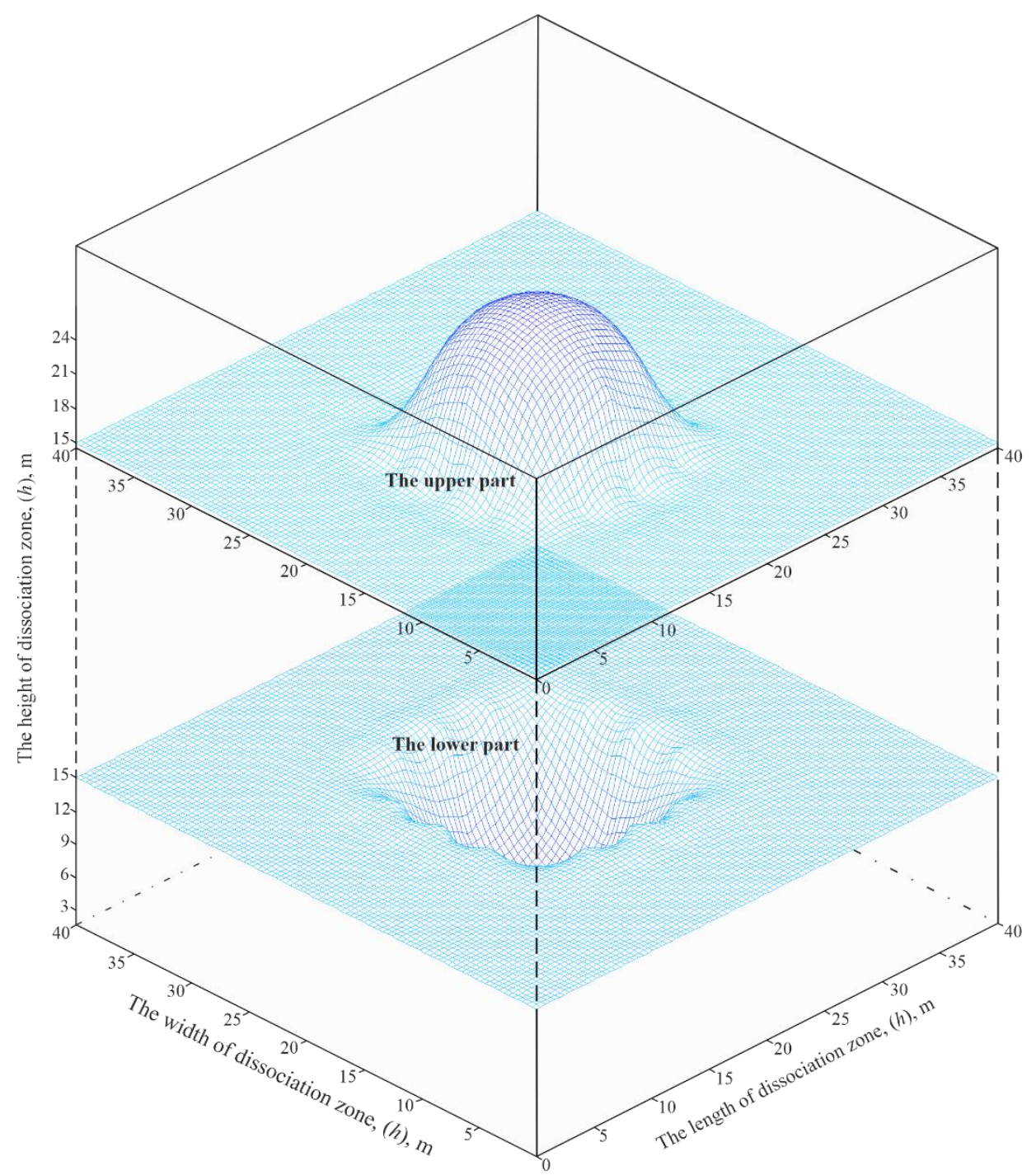

Figure 9. 3D grid-visualization of the upper and lower parts of the gas hydrate deposit (the share of rock intercalation $=30 \%$ ).

In Figure 9, the upper and lower surfaces are combined by a horizontal plane $z=0$. This value is specified in coordinate measurement units $(z=15)$. Each of the surfaces is specified by a grid function defined by a grid file. Since both surfaces are defined by the grid file of a horizontal plane, they have the same ranges of change in the coordinates $x$ and $y$, as well as the same number of lines and columns. In total, five 3D grid-visualizations have been constructed with changes in the shares of rock intercalation from 0 to $60 \%$ at increments of $15 \%$. Figure 10 shows the model of the dissociation zone cross-sections of the gas hydrate deposits within the given geometric parameters of the formed zones.

Analyzing the data (Figure 10), it is evident that the pure gas hydrate dissociation zone, which does not contain any rock intercalation, is the largest. Given the scale factor, it is $23.6 \mathrm{~m}$. Thus, the gas recovery factor of a gas hydrate deposit which does not contain intercalation is intense: the volume of gas output is 1.03 million $\mathrm{m}^{3}$.

Studying the dissociation peculiarities of the gas-hydrate deposit with a heterogeneous structure with a $15 \%$ intercalation share, it can be argued that the dissociation zone diameter is $21.8 \mathrm{~m}$, and that this amount of rock particles does not significantly influence the dissociation process. The volume of gas obtained during the dissociation of this gas hydrate deposit is 0.56 million $\mathrm{m}^{3}$. 


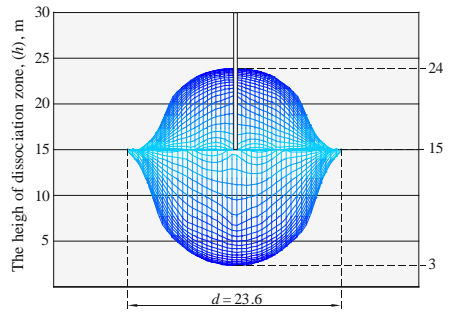

(a)

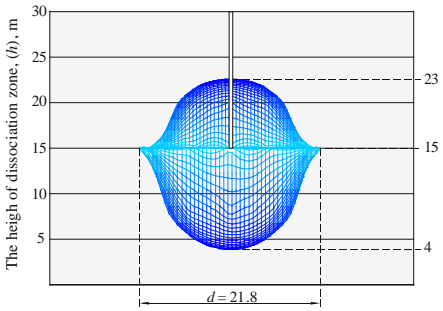

(b)

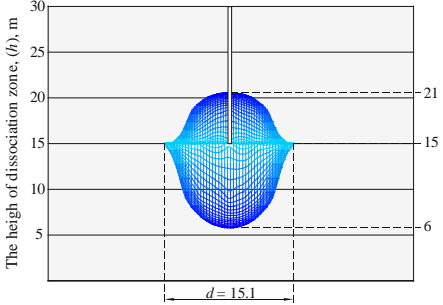

(d)

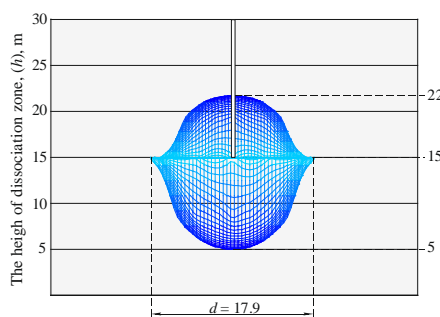

(c)

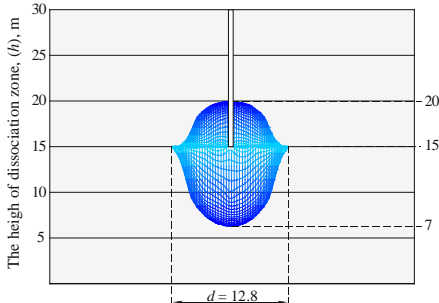

(e)

Figure 10. Dissociation zone cross-sections of the gas hydrate deposits with changing shares of rock intercalation: (a) $0 \%$; (b) 15\%; (c) 30\%; (d) 45\%; (e) 60\%.

With a $30 \%$ intercalation share, the dissociation zone diameter is $17.9 \mathrm{~m}$, a reduction of $5.7 \mathrm{~m}$ in comparison with the prototype pure gas hydrate deposit. This share of rock intercalation is most typical for gas hydrate deposits and is most often found in nature. The gas recovery factor of this type of deposit during dissociation is intense and the volume of methane gas output is 0.28 million $\mathrm{m}^{3}$. With an increase in the share of intercalation in the gas hydrate up to $45 \%$, the dissociation zone diameter decreases by $8.5 \mathrm{~m}$ in comparison with the gas hydrate deposit which does not contain rock intercalation at all, and its value is $15.1 \mathrm{~m}$. The gas recovery factor for this zone is less, since almost half of the deposit contains rock intercalation, amounting to 0.13 million $\mathrm{m}^{3}$. The smallest diameter of dissociation zone is where the rock intercalation share is at $60 \%$. This diameter is $12.8 \mathrm{~m}$, which is almost two times less than the diameter present in the dissociation of the gas hydrate which does not contain any rock particles at all. The gas recovery factor during this dissociation is the lowest, amounting to 0.05 million $\mathrm{m}^{3}$.

If the geometrical parameter values of the dissociation zones and their coordinate locations are known, the total volumes can be calculated. Having chosen the volume command in the grid menu of the Surfer- 8.0 software, with all the necessary spatial value parameters of the coordinate points set previously, an automatic volume calculation is performed. The volume between two surfaces is the sum of the positive (cut) and negative (fill) volumes. The volumes of surface flat sections in calculations are represented as the positive, negative, and horizontal areas of the flat surface sections of the object. These sections of the object, where the upper and lower surfaces of the volumes coincide, are not taken into account in the calculations.

The proposed method for determining the volume of the dissociation zones using the Surfer-8.0 software program makes it possible with a sufficiently high accuracy to determine the volumes and radii of the dissociation zones of gas hydrate deposits, depending on the share of rock intercalation. 
As a research result, the dependences of a change in the radius of the hydrate deposit dissociation zone on the share of rock intercalation in it have been obtained (Figure 11), as has the dependence of the dissociation process duration on the deposit dissociation zone radius (Figure 12).

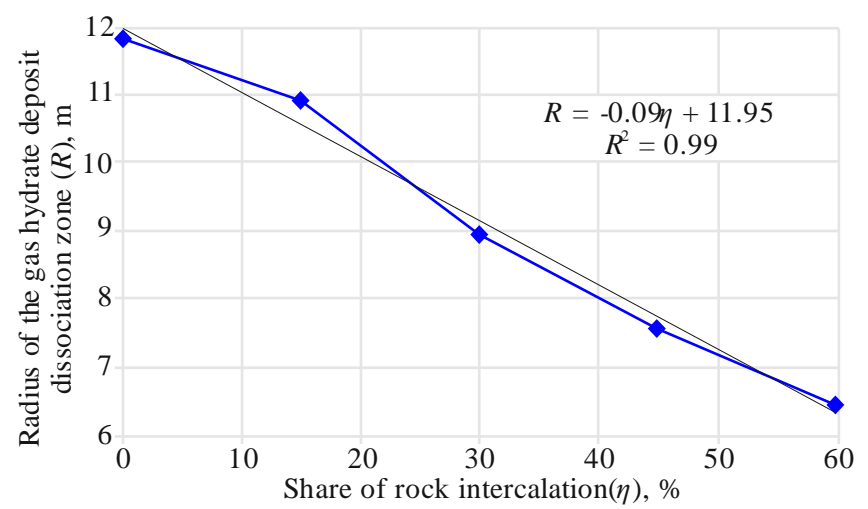

Figure 11. Dependence of a change in the radius of the dissociation zone on the share of rock intercalation.

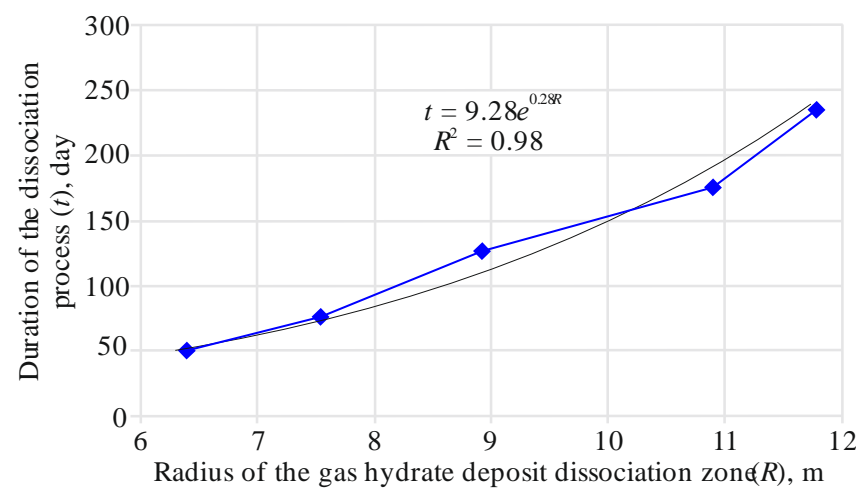

Figure 12. Dependence of a change in the duration of the dissociation process on the dissociation zone radius of the gas hydrate deposit.

It has been revealed that the dissociation process duration of the gas hydrate deposit containing a share of rock intercalation is approximated by the equation $t=9.28 e^{0.28 R}$, $\left(R^{2}=0.98\right)$. It has been determined that the dissociation process effective time $(t)$ of a gas hydrate deposit with a heterogeneous structure changes exponentially depending on the radius of its dissociation zone $(R)$, which increases with a decrease in the amount of rock intercalation $(\eta)$. In taking this dependence into account, it is possible to ensure a stable flow rate of the producing wells during the development of gas hydrate fields, with their positioning subsequently predicted.

\section{Conclusions}

The analysis of the geological-geophysical data and literature materials on the study of the Black Sea offshore area and the seabed has been conducted in order to identify the gas hydrate deposits. Since the Black Sea sediments, ranging from the depths of 500-600 m, are gassed with methane, most of the sea is favorable for hydrate formation. Therefore, there are significant gas hydrate deposits in the Black Sea, the gas reserves of which are estimated by researchers to be 100 trillion $\mathrm{m}^{3}$ of gas, with the area directly opposite the Crimean Peninsula containing 20-25 trillion $\mathrm{m}^{3}$ [48-50].

It has been found that no pure gas hydrate deposits prevail in the Black Sea basin, but rather deposits are of a heterogeneous structure, that is, they contain a certain share of rock aluminosilicate intercalation. 
Gas hydrates of pure methane and hydrates of a heterogeneous structure with different shares of rock intercalation (from 15 to $60 \%$ ) have been obtained in laboratory conditions. Gas hydrate deposits of a heterogeneous structure have been formed, which were subject to further dissociation. The dependence of hydrate accumulation on the time of the hydrate formation process at variable thermobaric parameters has been set.

The parameters of the dissociation zone of gas hydrate deposits with different shares of rock intercalation have been determined, and the 3D grid-visualization of the developed upper and lower parts of these deposits in the Black Sea basin has been constructed. It has been found that the diameter of the pure gas hydrate dissociation zone, which amounts to $23.6 \mathrm{~m}$, is the largest. In this case, its gas recovery factor is also at a maximum and amounts to 1.03 million $\mathrm{m}^{3}$ of gas. The gas hydrate deposit with a rock intercalation share of $60 \%$ has a dissociation zone diameter of $12.8 \mathrm{~m}$ and is the smallest, with a gas recovery factor of 0.05 million $\mathrm{m}^{3}$.

Using the Surfer-8.0 software program, having previously set the necessary parameters of the coordinate point spatial values, the dissociation zone volumes have been calculated, formed during the gas hydrate deposit dissociation with a variable share of rock intercalation.

The effective time of the dissociation process of gas hydrate deposits with different shares of rock intercalation has been substantiated, which changes exponentially depending on the radius of their dissociation zone and is approximated by the equation $t=9.28 e^{0.28 R}$, $\left(R^{2}=0.98\right)$.

The dependence of a change in the radius of the hydrate deposit dissociation zone on the variable share of rock intercalation in it $(0-60 \%)$ has been obtained. The change in radius is described by the equation $R=-0.09 \eta+11.95$, with an accuracy of $R^{2}=0.99$.

Author Contributions: Conceptualization, O.B.; Methodology, K.S.; Software, V.L.; Validation, K.S., P.S.; Formal analysis, M.P. and P.S.; Investigation, K.S. and P.S.; Resources, P.S.; Data curation, K.S.; Writing-original draft preparation, K.S. and M.P.; Writing-review and editing, K.S. and V.L.; Visualization, V.L.; Supervision, O.B.; Project administration, O.B.; Funding acquisition, O.B. All authors have read and agreed to the published version of the manuscript.

Funding: This study was carried out as part of the project "Belt and Road Initiative Centre for ChineseEuropean studies" and was funded by the Guangdong University of Petrochemical Technology.

Institutional Review Board Statement: Not applicable.

Informed Consent Statement: Not applicable.

Data Availability Statement: Data is contained within the article.

Acknowledgments: The team of authors expresses their gratitude to the reviewers for their valuable recommendations that have been taken into account to improve significantly the quality of this paper.

Conflicts of Interest: The authors declare no conflict of interest.

\section{References}

1. Panchuk, M.; Kryshtopa, S.; Panchuk, A.; Kryshtopa, L.; Dolishnii, B.; Mandryk, I.; Sladkowski, A. Perspectives for developing and using the torrefaction technology in Ukraine. Int. J. Energy Clean Environ. 2019, 20, 113-134. [CrossRef]

2. Deb, M.; Sarkar, S.C. Energy Resources. In Minerals and Allied Natural Resources and their Sustainable Development. Springer Geology; Springer: Singapore, 2017; pp. 351-419. [CrossRef]

3. Petlovanyi, M.V.; Lozynskyi, V.H.; Saik, P.B.; Sai, K.S. Modern experience of low-coal seams underground mining in Ukraine. Int. J. Min. Sci. Technol. 2018, 28, 917-923. [CrossRef]

4. Piddubna, D.; Karakash, I. Legal regulation of natural resources as a category of environmental resources for providing economic activity on the example of Ukraine. Eur. J. Sustain. Dev. 2020, 9, 228-242. [CrossRef]

5. Sribna, Y.; Trokhymets, O.; Nosatov, I.; Kriukova, I. The globalization of the world coal market-Contradictions and trends. E3S Web Conf. 2019, 123, 01044. [CrossRef]

6. Dychkovskyi, R.; Vladyko, O.; Maltsev, D.; Cabana, E.C. Some aspects of the compatibility of mineral mining technologies. Rud.-Geol.-Naft. Zb. 2018, 33, 73-82. [CrossRef]

7. Kirin, R.; Hryshchak, S.; Illarionov, O. Features of legal support for the operation of small atypical Ukrainian coal mines under contractual conditions of a public-private partnership. Min. Miner. Depos. 2020, 14, 128-137. [CrossRef] 
8. Bazaluk, O.; Petlovanyi, M.; Lozynskyi, V.; Zubko, S.; Sai, K.; Saik, P. Sustainable Underground Iron Ore Mining in Ukraine with Backfilling Worked-Out Area. Sustainability 2021, 13, 834. [CrossRef]

9. Haiko, H.; Saik, P.; Lozynskyi, V. The Philosophy of Mining: Historical Aspect and Future Prospect. Philos. Cosmol. 2019, 22, 76-90. [CrossRef]

10. Sachsenhofer, R.F.; Privalov, V.A.; Panova, E.A. Basin evolution and coal geology of the Donets Basin (Ukraine, Russia): An overview. Int. J. Coal Geol. 2012, 89, 26-40. [CrossRef]

11. Law, B.E.; Ulmishek, G.F.; Clayton, J.L.; Kabyshev, B.P.; Pashova, N.T.; Krivosheya, V.A. Basin-centered gas evaluated in Dnieper-Donets basin, Donbas foldbelt, Ukraine. Oil Gas J. 1998, 96, 74-78.

12. Petlovanyi, M.; Malashkevych, D.; Sai, K.; Zubko, S. Research into balance of rocks and underground cavities formation in the coal mine flowsheet when mining thin seams. Min. Miner. Depos. 2020, 14, 66-81. [CrossRef]

13. Sabishchenko, O.; Rębilas, R.; Sczygiol, N.; Urbański, M. Ukraine energy sector management using hybrid renewable energy systems. Energies 2020, 13, 1776. [CrossRef]

14. Małkowski, P.; Niedbalski, Z.; Hydzik-WiŚniewska, J. The change of structural and thermal properties of rocks exposed to high temperatures in the vicinity of designed geo-reactor. Arch. Min. Sci. 2013, 584, 465-480. [CrossRef]

15. Falshtynskyi, V.; Saik, P.; Lozynskyi, V.; Dychkovskyi, R.; Petlovanyi, M. Innovative aspects of underground coal gasification technology in mine conditions. Min. Miner. Depos. 2018, 12, 68-75. [CrossRef]

16. Saik, P.; Petlevanyi, M.; Lozynskyi, V.; Sai, K.; Merzlikin, A. Innovative approach to the integrated use of energy resources of underground coal gasification. Solid State Phenom. 2018, 277, 221-231. [CrossRef]

17. Ganushevych, K.; Sai, K.; Korotkova, A. Creation of gas hydrates from mine methane. In Progressive Technologies of Coal, Coalbed Methane, and Ores Mining; CRC Press: London, UK, 2014; pp. 505-509. [CrossRef]

18. Du, J.; Li, H.; Wang, L. Thermodynamic stability conditions, methane enrichment, and gas uptake of ionic clathrate hydrates of mine ventilation air. Chem. Eng. J. 2015, 273, 75-81. [CrossRef]

19. Tolmachev, O.; Urunov, A.; Muminova, S.; Dvoichenkova, G.; Davydov, I. Review of unconventional hydrocarbon resources:production technologies and opportunities for development. Min. Miner. Depos. 2020, 14, 113-121. [CrossRef]

20. Bondarenko, V.; Lozynskyi, V.; Sai, K.; Anikushyna, K. An overview and prospectives of practical application of the biomass gasification technology in Ukraine. In New Developments in Mining Engineering 2015: Theoretical and Practical Solutions of Mineral Resources Mining; CRC Press: London, UK, 2015; pp. 27-32. [CrossRef]

21. Ursul, A.; Ursul, T. Environmental Education for Sustainable Development. Future Hum. Image 2018, 9, 115-125. [CrossRef]

22. Proedrou, F. EU energy security beyond Ukraine: Towards holistic diversification. Eur. Foreign Aff. Rev. 2016, $21,57-74$.

23. Leal-Arcas, R.; Alemany Ríos, J.; Grasso, C. The European Union and its energy security challenges: Engagement through and with networks. Contemp. Politics 2015, 21, 273-293. [CrossRef]

24. Janeliunas, T.; Tumkevič, A. Securitization of the energy sectors in Estonia, Lithuania, Poland and Ukraine: Motives and extraordinary measures. Lith. Foreign Policy Rev. 2013, 30, 65-95.

25. Sekerin, V.; Dudin, M.; Gorokhova, A.; Bank, S.; Bank, O. Mineral resources and national economic security: Current features. Min. Miner. Depos. 2019, 13, 72-79. [CrossRef]

26. Bocse, A.M. From the United States with shale gas: Ukraine, energy securitization, and the reshaping of transatlantic energy relations. Energy Res. Soc. Sci. 2020, 69, 101553. [CrossRef]

27. Fialko, N.; Tymchenko, M. Ukraine Energy Transition in Light of the EU Experience. Lect. Notes Civ. Eng. 2021, 100, 112-117. [CrossRef]

28. Szurlej, A.; Łaciak, M.; Boiko, O.; Olijnyk, A. The natural gas sector in Ukraine-Opportunities and barriers to growth. Polityka Energetyczna 2019, 22, 115-128. [CrossRef]

29. Bayramov, A.; Marusyk, Y. Ukraine's unfinished natural gas and electricity reforms: One step forward, two steps back. Eurasian Geogr. Econ. 2019, 60, 73-96. [CrossRef]

30. Goncharuk, A.G.; Cirella, G.T. A perspective on household natural gas consumption in Ukraine. Extr. Ind. Soc. 2020, 7, 587-592. [CrossRef]

31. Annual Report of Naftogaz; Naftogaz Group: Kyiv, Ukraine, 2019; 125p.

32. Paranytsia, N.V. Rehresiinyi analiz pokaznykiv publichnoho aktsionernoho tovarystva «Natsionalna aktsionerna kompaniia «Naftohaz Ukrainy». Finansy Oblik Opodatkuvannia 2018, 2, 146-152. [CrossRef]

33. Derkach, O.; Metoshop, O.A. Influence of factors of external and internal environment on formation of image of managers (on the example of «Naftogaz» of Ukraine). Bus. Navig. 2020, 57, 105-110. [CrossRef]

34. Kucherenko, O.; Smyrnova, K.; Letunovska, I. Reforming the natural gas market in Ukraine: The process of unbandling (unbundling case). EEA Electroteh. Electron. Autom. 2020, 68, 80-85. [CrossRef]

35. Sharples, J.D. The international political economy of eastern European energy security: Russia, Ukraine, and the European Union In Oxford Handbook of Energy and Society; Oxford University Press: Oxford, UK, 2018; pp. 137-164. [CrossRef]

36. Maslin, M.; Owen, M.; Betts, R.; Day, S.; Jones, T.D.; Ridgwell, A. Gas hydrates: Past and future geohazard? Math. Phys. Eng. Sci. 2010, 368, 2369-2393. [CrossRef]

37. Claes, D.H.; Moe, A. Arctic offshore petroleum: Resources and political fundamentals. In Arctic Governance; Bloomsbury Publishing: London, UK, 2018; Volume 2. [CrossRef] 
38. Ishchenko, V. Offshore renewable energy development: U.S. experience and takeaways for Ukraine. Lex Portus 2020, 3, 7-23. [CrossRef]

39. Goshovskyi, S. Gas seeps as the black sea hydrocarbon resource. Surv. Geol. Min. Ecol. Manag. 2019, 19, 877-882. [CrossRef]

40. Nasif, A.; Özel, F.E.; Dondurur, D. Seismic identification of gas hydrates: A case study from Sakarya Canyon, western Black Sea. Turk. J. Earth Sci. 2020, 29, 434-454. [CrossRef]

41. Gassner, L.; Gerach, T.; Hertweck, T.; Bohlen, T. Seismic characterization of submarine gas-hydrate deposits in the Western Black Sea by acoustic full-waveform inversion of ocean-bottom seismic data. Geophysics 2019, 84, B311-B324. [CrossRef]

42. Bonnefoy, O.; Gruy, F.; Herri, J.M. Van der Waals interactions in systems involving gas hydrates. Fluid Phase Equilibria 2005, 231, 176-187. [CrossRef]

43. Porgar, S. Study on Process of Gas Hydrate Formation; Lambert Academic Publishing: Saarbrücken, Germany, 2019; pp. 1-122. ISBN 978-613-9453-53-5.

44. Makogon, Y.F. Gazogidraty. Istoriya izucheniya i perspektivy osvoeniya. Geol. Polezn. Iskop. Mirovogo Okeana $2010,2,5-21$.

45. Makogon, Y.F. Hydrates of Hydrocarbons; PennWell Corporation: Tulsa, OK, USA, 1997; pp. 14-82. ISBN 1978-087-8147-18-2.

46. Hassanpouryouzband, A.; Joonaki, E.; Vasheghani Farahani, M.; Takeya, S.; Ruppel, C.; Yang, J.; English, N.J.; Schicks, J.M.; Edlmann, K.; Mehrabian, H.; et al. Gas hydrates in sustainable chemistry. Chem. Soc. Rev. 2020, 49, 5225-5309. [CrossRef]

47. Zhang, Z. Heat Transfer during the Dissociation of Hydrate in Porous Media. Procedia Eng. 2015, 126, 502-506. [CrossRef]

48. Korsakov, O.D.; Byakov, Y.A.; Stupak, S.N. Gas hydrates in the Black Sea basin. Int. Geol. Rev. 1989, 31, 1251-1257. [CrossRef]

49. Ginsburg, G.D.; Kremlev, A.N.; Grigor'yev, M.N.; Pavlenkin, A.D.; Larkin, G.V.; Tsar'kov, V.Y. Discovery of solid gas hydrate in the rock at the foot of the continental slope of the Crimea. Doklady. Earth Sci. Sect. 1989, 309, 83-85.

50. Makogon, Y.F.; Holditch, S.A.; Makogon, T.Y. Natural gas-hydrates-A potential energy source for the 21st Century. J. Pet. Sci. Eng. 2007, 56, 14-31. [CrossRef]

51. Parlaktuna, M.; Erdogmuş, T. Natural gas hydrate potential of the Black Sea. Energy Sources 2010, 23, 203-211. [CrossRef]

52. Merey, S.; Sinayuc, C. Investigation of gas hydrate potential of the Black Sea and modeling of gas production from a hypothetical Class 1 methane hydrate reserve in the Black Seanditions. J. Nat. Gas Sci. Eng. 2016, 29, 66-79. [CrossRef]

53. Nair, V.C.; Gupta, P.; Sangwai, J.S. Gas Hydrates as a potential energy resource for energy sustainability. In Sustainable Energy Technology and Policies; Green Energy and Technology Book Series; Springer: Singapore, 2018; pp. 265-287. [CrossRef]

54. Hanushevych, K.; Srivastava, V. Coalbed methane: Places of origin, perspectives of extraction, alternative methods of transportation with the use of gas hydrate and nanotechnologies. Min. Miner. Depos. 2017, 11, 23-33. [CrossRef]

55. Sabitova, D.K. Exploration Potential of Coalbed Methane in Karaganda Field. Mod. Appl. Sci. 2015, 9, 145-159. [CrossRef]

56. Kvamme, B.; Zhao, J.; Wei, N.; Saeidi, N. Hydrate-A mysterious phase or just misunderstood? Energies 2020, 13, 880. [CrossRef]

57. Giavarini, C.; Hester, K. The structure and formation of gas hydrates. Green Energy Technol. 2011, 23-47. [CrossRef]

58. Kastner, M. Gas hydrates in convergent margins: Formation, occurrence, geochemistry, and global significance. In Natural Gas Hydrates: Occurrence, Distribution, and Detection; Geophysical Monograph Series; American Geophysical Union: Washington, DC, USA, 2013; pp. 67-86. [CrossRef]

59. Carroll, J. Combating hydrates using heat and pressure. In Natural Gas Hydrates; Gulf Professional Publishing: Houston, TX, USA, 2014; pp. 197-229. [CrossRef]

60. Bondarenko, V.; Sai, K.; Ganushevych, K.; Ovchynnikov, M. The results of gas hydrates process research in porous media. In New Developments in Mining Engineering 2015: Theoretical and Practical Solutions of Mineral Resources Mining; CRC Press: London, UK, 2015; pp. 123-127. [CrossRef]

61. Misyura, S.Y. Dissociation of various gas hydrates (methane hydrate, double gas hydrates of methane-propane and methaneisopropanol) during combustion: Assessing the combustion efficiency. Energy 2020, 206, 118120. [CrossRef]

62. Melnikov, V.; Gennadinik, V. Cryodiversity: The World of Cold on the Earth and in the Solar System. Philos. Cosmol. 2018, 20, 43-54. [CrossRef] [PubMed]

63. Bondarenko, V.; Ganushevych, K.; Sai, K.; Tyshchenko, A. Development of gas hydrates in the Black Sea. In Technical and Geoinformational Systems in Mining; CRC Press: London, UK, 2011; pp. 55-59. [CrossRef]

64. Bondarenko, V.; Sai, K.; Prokopenko, K.; Zhuravlov, D. Thermodynamic and geomechanical processes research in the development of gas hydrate deposits in the conditions of the Black Sea. Min. Miner. Depos. 2018, 12, 104-115. [CrossRef]

65. Sai, K.; Malanchuk, Z.; Petlovanyi, M.; Saik, P.; Lozynskyi, V. Research of thermodynamic conditions for gas hydrates formation from methane in the coal mines. Solid State Phenom. 2019, 291, 155-172. [CrossRef]

66. Pedchenko, L.; Nyemchenko, K.; Pedchenko, N.; Pedchenko, M. Use of alternative energy sources to improve the efficiency of natural gas hydrate technology for gas offshore deposits transportation. Min. Miner. Depos. 2018, 12, 122-131. [CrossRef]

67. Moridis, G.J.; Collett, T.S.; Boswell, R.; Kurihara, M.; Reagan, M.T. Toward production from gas hydrates: Assessment of resources, technology and potential. SPE Unconv. Reserv. Conf. 2008, 42. [CrossRef]

68. Gaurina-Međimurec, N.; Novak-Mavar, K.; Majić, M. CCS technology: Overview of projects, technology and monitoring. Rud.-Geol.-Naft. Zb. 2018, 33, 1-14. [CrossRef]

69. Moridis, G.J.; Collett, T.S.; Pooladi-Darvish, M.; Hancock, S.H.; Santamarina, J.C.; Boswell, R.; Koh, C. Challenges, uncertainties and issues facing gas production from hydrate deposits in geologic systems. SPE Unconv. Gas Conf. 2010, 46. [CrossRef]

70. Matsuzawa, M.; Umeza, S.; Yamamoto, K. Evaluation of experiment program 2004: Natural hydrate exploration campaign in the Nankai-Trough offshore Japan. IADC/SPE Drill. Conf. 2006. [CrossRef] 
71. Nischal, R.; Kumar, S.; Arora, S.; Mitra, N.K. Overview and outlook of natural gas scenario in India: A case study. Int. Pet. Technol. Conf. 2008. [CrossRef]

72. Techniques for the Quantification of Methane Hydrate in European Continental Margins (HYDRATECH). Available online: https:/ / cordis.europa.eu/project/id/EVK3-CT-2000-00043 (accessed on 14 December 2020).

73. Geological Assessment of Gas Hydrates in the Mediterranean Sea. Available online: https://cordis.europa.eu/project/id/501814 /reporting (accessed on 14 December 2020).

74. Mienert, J.; Vanneste, M.; Bünz, S.; Andreassen, K.; Haflidason, H.; Sejrup, H.P. Ocean warming and gas hydrate stability on the mid-Norwegian margin at the Storegga Slide. Mar. Pet. Geol. 2005, 22, 233-244. [CrossRef]

75. Lorenson, T.D.; Collett, T.S.; Whiticar, M.J. Hydrocarbon gas composition and origin of gas hydrate from the Alaska North Slope; American Association of Petroleum Geologists: Tulsa, OK, USA, 2009; pp. 584-597. [CrossRef]

76. Hupp, D.; Burt, J.; Blades, A.J. Petrophysical evaluation of natural gas hydrates-North Slope, Alaska. SPE West. Reg. Meet. 2016. [CrossRef]

77. Dillon, W.P.; Max, M.D. Oceanic gas hydrate. In Natural Gas Hydrate in Oceanic and Permafrost Environments; Springer: Dordrecht, The Netherlands, 2003; pp. 61-76. [CrossRef]

78. Burwicz, E.; Reichel, T.; Wallmann, K.; Rottke, W.; Haeckel, M.; Hensen, C. 3-D basin-scale reconstruction of natural gas hydrate system of the Green Canyon, Gulf of Mexico. Geochem. Geophys. Geosyst. 2017, 18, 1959-1985. [CrossRef]

79. Foucher, J.-P.; Nouzé, H.; Henry, P. Observation and tentative interpretation of a double BSR on the Nankai slope. Mar. Geol. 2002, 187, 161-175. [CrossRef]

80. Matsumoto, R.; Tomaru, H.; Lu, H. Detection and evaluation of gas hydrates in the Eastern Nankai Trough by geochemical and geophysical methods. Resour. Geol. 2004, 54, 53-67. [CrossRef]

81. Collett, T.S. Natural gas hydrate as a potential energy resource. In Natural Gas Hydrate in Oceanic and Permafrost Environments; Springer: Dordrecht, The Netherlands, 2003; pp. 123-136. [CrossRef]

82. Demirbas, A. Methane from gas hydrates in the Black Sea. Energy Sources Part A Recover. Util. Environ. Eff. 2009, 32, 165-171. [CrossRef]

83. Liang, F.; Wang, C.; Tang, G. Experimental investigation on gas hydrate recovery using temperature separation mechanism of vortex tube. Energy 2000, 212, 118749. [CrossRef]

84. Gambelli, A.M.; Castellani, B.; Nicolini, A.; Rossi, F. Experimental study on natural gas hydrate exploitation: Optimization of methane recovery, carbon dioxide storage and deposit structure preservation. J. Pet. Sci. Eng. 2019, 177, 594-601. [CrossRef]

85. Rogers, R. Producing methane from offshore hydrates. In Offshore Gas Hydrates; Gulf Professional Publishing: Houston, TX, USA, 2015; pp. 101-133. [CrossRef]

86. Rossi, F.; Gambelli, A.M.; Sharma, D.K.; Castellani, B.; Nicolini, A.; Castaldi, M.J. Experiments on methane hydrates formation in seabed deposits and gas recovery adopting carbon dioxide replacement strategies. Appl. Therm. Eng. 2019, 148, 371-381. [CrossRef]

87. Ganushevych, K.; Sai, K. Technological aspects of the development of gas hydrate deposits with the use of carbon dioxide injection. E3S Web Conf. 2020, 201, 01023. [CrossRef]

88. Kamath, V.A.; Mutalik, P.N.; Sira, J.H.; Patil, S.L. Experimental study of brine injection depressurization of gas hydrates dissociation of gas hydrates. SPE Form. Eval. 1991, 6, 477-484. [CrossRef]

89. Gambelli, A.M.; Castellani, B.; Filipponi, M.; Nicolini, A.; Rossi, F. Chemical inhibitors as potential allied for $\mathrm{CO}_{2}$ replacement in gas hydrates reservoirs: Sodium chloride case study. In Proceedings of the World Congress on Mechanical, Chemical, and Material Engineering, Prague, Czech Republic, 18 August 2020. ICCPE 111. [CrossRef]

90. Zhang, Q. The hydrates dissociation rate measurement for natural gas recovery from hydrates sediment. In Proceedings of the 2010 Asia-Pacific Power and Energy Engineering Conference, Chengdu, China, 28-31 March 2010; pp. 1-4. [CrossRef]

91. Burnol, A. Roles of gas hydrates for $\mathrm{CO}_{2}$ geological storage purposes. Gas Hydrates 2018, 2, 267-284. [CrossRef]

92. Merey, S. Well completion operations in gas hydrate reservoirs. Int. J. Oil Gas Coal Technol. 2018, 20, 373-396. [CrossRef]

93. Bhade, P.; Phirani, J. Gas production from layered methane hydrate reservoirs. Energy 2015, 82, 686-696. [CrossRef]

94. Meng, Q.; Liu, C.; Chen, Q.; Ye, Y. Natural gas hydrate dissociation. In Natural Gas Hydrates; Gulf Professional Publishing: Houston, TX, USA, 2012; pp. 261-283. [CrossRef]

95. Shnyukov, Y.F.; Kobolev, V.P. Gas hydrates of Black Sea-Potential source of energy (analytical review). Geol. Miner. Resour. World Ocean 2017, 13, 5-23. [CrossRef]

96. Burwicz, E.; Haeckel, M. Basin-scale estimates on petroleum components generation in the Western Black Sea basin based on 3-D numerical modelling. Mar. Pet. Geol. 2020, 113, 104-122. [CrossRef]

97. Shnyukov, E.F. Mud volcanoes of the Black Sea as a prospecting indicator of methane gas hydrates. Lithol. Miner. Resour. 2013, 48, 114-121. [CrossRef]

98. Lüdmann, T.; Wong, H.; Konerding, P.; Zillmer, M.; Petersen, J.; Flöh, E. Heat flow and quantity of methane deduced from a gas hydrate field in the vicinity of the Dnieper Canyon, northwestern Black Sea. Geo-Mar. Lett. 2004, 24, 182-193. [CrossRef]

99. Shnyukov, E.F. Gazogidraty metana v Chernom more. Geol. Polezn. Iskop. Mirovogo Okeana 2005, 2, 41-52.

100. Sloan, E.D.; Koh, C.A.; Sum, A.K. Gas Hydrate Stability and Sampling: The Future as Related to the Phase Diagram. Energies 2010, 3, 1991-2000. [CrossRef] 
101. Husebø, J.; Ersland, G.; Graue, A.; Kvamme, B. Effects of salinity on hydrate stability and implications for storage of $\mathrm{CO}_{2}$ in natural gas hydrate reservoirs. Energy Procedia 2009, 1, 3731-3738. [CrossRef]

102. Egorov, V.N.; Artemov, Y.G.; Gulin, S.B. Methane Seeps in the Black Sea: Environmental and Ecological Role; SPC ECOSI-Hydrophysics: Sevastopol, Ukraine, 2011; pp. 1-405.

103. Artemov, Y.G.; Egorov, V.N.; Gulin, S.B. Intake of jet methane into the anoxic waters of the Black Sea depression. Oceanology 2019, 59, 952-963. [CrossRef]

104. Bondarenko, V.; Maksymova, E.; Sai, K.; Ovchynnikov, M.; Ganushevych, K. Gas hydrates. In Gas Hydrates Formation and Basics of Their Recovery; Litograf: Dnipropetrovsk, Ukraine, 2015; pp. 1-219. ISBN 978-966-2267-84-6.

105. Bogoyavlensky, V.I.; Yanchevskaya, A.S. Features of the Earth Degassing and Gas Hydrates Distribution in the Black Sea. Geomodel 2020, 2020, 1-5. [CrossRef]

106. Vassilev, A.; Dimitrov, L. Model evaluation of the Black Sea gas hydrates. C. R. L'Acad. Bulg. Sci. 2003, 56, 3-15.

107. Sloan, E.D.; Koh, C.A. Clathrate Hydrates Natural Gases; CRC Press Taylor \& Francis Group: New York, NY, USA, $2007 ;$ pp. 1-752. ISBN 978-0824782962. [CrossRef]

108. Kutas, R.I. Geotectonic and geothermal conditions of the gas discharge zones in the Black Sea. Geophys. J. 2020, 42, 16-52. [CrossRef]

109. Kobolev, V.P.; Kutas, R.I.; Tsvyashchenko, V.A.; Kravchuk, O.P.; Bevzyuk, M.I. Geothermal studies in the north-western part of the Black Sea. Geophys. J. 1993, 13, 355-371.

110. Dmitrievsky, A.N.; Balanyuk, I.E. Gas Hydrates of Seas and Oceans-A Hydrocarbon Source of the Future; Federation Gazprom LTD.: Moscow, Russia, 2009; pp. 1-416.

111. Kutas, R.I.; Kobolev, V.P.; Tsvyashchenko, V.A.; Kravchuk, O.P.; Bevzyuk, M.I. Geothermal aspects of the formation of gas hydrates in the Black Sea basin. Geophys. J. 1996, 18, 20-27.

112. Vorobiev, A.; Bolatova, A.; Moldabaeva, G.; Chekushina, E. Expert evaluation of the current world aquatic gas hydrate reserves. Drill. Oil 2011, 12, 48-56.

113. Olaru, R.; Krézsek, C.; Rainer, T.M.; Ungureanu, C.; Turi, V.; Ionescu, G.; Tari, G. 3D basin modelling of Oligocene-Miocene Maikop source rocks offshore Romania and in the western black sea. J. Pet. Geol. 2018, 41, 351-365. [CrossRef]

114. Duchkov, A.D.; Kazantsev, S.A. Thermal flow of the Black Sea depression. In Geophysical Fields of the Atlantic Ocean; Trofimuk Institute of Petroleum Geology and Geophysics, Siberian Branch of Russian Academy of Sciences: Novosibirsk, USSR, 1988; pp. 121-130.

115. Ivanov, M.K.; Limonov, A.F.; Woodside, J.M. Extensive deep fluid flux through the sea floor on the Crimean continental margin (Black Sea). Geol. Soc. Lond. Spec. Publ. 1998, 137, 195-213. [CrossRef]

116. Aliyev, A.A.; Kabulova, A.Y.; Rahmanov, R.R. Gashydrates, gas seeps and pockmarks in the zones of development of mud volcanism Mediterranean, Black and Caspian seas. Miner. Resour. Ukr. 2019, 2, 25-33. [CrossRef]

117. Bondarenko, V.; Svietkina, O.; Sai, K. Study of the formation mechanism of gas hydrates of methane in the presence of surfaceactive substances. East.-Eur. J. Enterp. Technol. 2017, 89, 48-55. [CrossRef]

118. Ovchynnikov, M.; Ganushevych, K.; Sai, K. Methodology of gas hydrates formation from gaseous mixtures of various compositions. In Mining of Mineral Deposits; Annual Scientific-Technical Colletion; CRC Press: London, UK, 2013; pp. 203-205. [CrossRef]

119. Makogon, Y.F. Natural gas hydrates-A promising source of energy. J. Nat. Gas Sci. Eng. 2010, 2, 49-59. [CrossRef]

120. Kvamme, B.; Iden, E.; Tveit, J.; Veland, V.; Zarifi, M.; Qorbani, K. Effect of $\mathrm{H}_{2} \mathrm{~S}$ Content on Thermodynamic Stability of Hydrate Formed from $\mathrm{CO}_{2} / \mathrm{N}_{2}$ Mixtures. J. Chem. Eng. Data 2017, 62, 1645-1658. [CrossRef]

121. Belosludov, V.; Bozhko, Y.; Subbotin, O.; Belosludov, R.; Zhdanov, R.; Gets, K.; Kawazoe, Y. Influence of $\mathrm{N}_{2}$ on Formation Conditions and Guest Distribution of Mixed $\mathrm{CO}_{2}+\mathrm{CH}_{4}$ Gas Hydrates. Molecules 2018, 23, 3336. [CrossRef] [PubMed]

122. Wijayanti, W. An effect of $\mathrm{CO}_{2}$ on the characteristic of gas hydrate in a vessel tank. AIP Conf. Proc. 2019, 2097, 030046. [CrossRef]

123. Pandey, J.; Solms, N. Hydrate Stability and Methane Recovery from Gas Hydrate through $\mathrm{CH}_{4}-\mathrm{CO}_{2}$ Replacement in Different Mass Transfer Scenarios. Energies 2019, 12, 2309. [CrossRef]

124. Pallipurath, M.I. Dissociation and subsidence of hydrated sediment: Coupled models. Energy Explor. Exploit. 2009, 27, 105-131. [CrossRef]

125. Falenty, A.; Kuhs, W.F.; Glockzin, M.; Rehder, G. "Self-preservation" of $\mathrm{CH}_{4}$ hydrates for gas transport technology: Pressuretemperature dependence and ice microstructures. Energy Fuels 2014, 28, 6275-6283. [CrossRef]

126. Majid, A.A.A.; Koh, C.A. Self-preservation phenomenon in gas hydrates and its application for energy storage. Intra-and InterMolecular Interactions between Non-Covalently Bonded Species; Elsevier: Amsterdam, The Netherlands, 2021; pp. 267-285. [CrossRef]

127. Bondarenko, V.; Svietkina, O.; Sai, K. Effect of mechanoactivated chemical additives on the process of gas hydrate formation. East.-Eur. J. Enterp. Technol. 2018, 91, 17-26. [CrossRef]

128. Wang, F.; Zhao, B.; Li, G. Prevention of potential hazards associated with marine gas hydrate exploitation: A review. Energies 2018, 11, 2384. [CrossRef]

129. Beaudoin, Y.C.; Dallimore, S.R.; Boswell, R. Frozen Heat: A Global Outlook on Methane Gas Hydrates; United Nations Environment Programme, GRID: Sioux Falls, SD, USA, 2014; ISBN 978-92-807-3319-8.

130. Yamamoto, K.; Dallimore, S. Aurora-JOGMEC-NRCan Mallik 2006-2008 gas hydrate research project progress. Nat. Gas Oil 2008, $304,1-5$. 
131. Hamer, G. BT technology for the control of methane emissions from permafrost and natural gas hydrates. In Comprehensive Biotechnology; Academic Press: Cambridge, MA, USA, 2011; pp. 701-707. [CrossRef]

132. Moridis, G.J. Numerical studies of gas production from methane hydrates. Gas Technol. Symp. 2002. [CrossRef]

133. Maksymova, E. Selecting the method of gas hydrate deposits development in terms of the regularities of their formation. Min. Miner. Depos. 2018, 12, 103-108. [CrossRef]

134. Lozynskyi, V.H. Substantiation int Parameters of Borehole Underground Coal Gasification Technology in the Faulting Zone; National Mining University (Dnipro University of Technology): Dnipro, Ukraine, 2015; pp. 1-156.

135. Light, W.A.; Cheney, E.W. On the approximation of a bivariate function by the sum of univariate functions. J. Approx. Theory 1980, 29, 305-322. [CrossRef]

136. Taimanov, I.A. Kartographia i krivizna. Kvant 2019, 1, 9-13. [CrossRef]

137. Zuska, A.V.; Shulichenko, A.O. Vyznachennia obiemiv porid, shcho zamishchuiutsia, z vykorystanniam prohramy Surfer. Heotekhnichni Problemy Rozrobky Rodovyshch 2008, 47, 295-300.

138. Vygodskyi, M.I. Spravochnik po Vyshei Matimatike; Nauka: Moskva, Russia, 1977; 870p.

139. Simpson, T.; Mistree, F.; Korte, J.; Mauery, T. Comparison of response surface and kriging models for multidisciplinary design optimization. In Proceedings of the 7th AIAA/USAF/NASA/ISSMO Symposium on Multidisciplinary Analysis and Optimization, St. Louis, MO, USA, 2-4 September 1998; pp. 47-55.

140. Hengl, T.; Heuvelink, G.B.M.; Rossiter, D.G. About regression-kriging: From equations to case studies. Comput. Geosci. 2007, 33, 1301-1315. [CrossRef]

141. Malvić, T. Kriging, cokriging orstochastical simulations, and the choice between deterministicor sequential approaches. Geol. Croat. 2008, 61, 37-47.

142. Malvić, T.; Ivšinović, J.; Velić, J.; Rajić, R. Kriging with a Small Number of Data Points Supported by Jack-Knifing, a Case Study in the Sava Depression (Northern Croatia). Geosciences 2019, 9, 36. [CrossRef]

143. Si, Z.; Li, S.; Huang, L.; Chen, Y. Visualization programming for batch processing of contour maps based on VB and Surfer software. Adv. Eng. Softw. 2010, 41, 962-965. [CrossRef] 